\title{
STATISTICS OF SPAIN'S COLONIAL TRADE, 1747-1820: NEW ESTIMATES AND COMPARISONS WITH GREAT BRITAIN *
}

\author{
JAVIER CUENCA-ESTEBAN \\ University of Waterloo ${ }^{\text {a }}$
}

\begin{abstract}
New estimates of Spain's current-account balance with the "Indies» add new perspectives to the recent debate on the aims and results of Spanish commercial policy. At the height of «comercio libre» in 1784-92, Spain's private commercial interests appear to have drawn larger financial returns from the Indies than did their British counterparts from wider colonial engagement. On this as on other scores, by the eve of the French wars the Spanish empire appears to have become a sounder economic proposition than might be inferred from recent pessimistic views. The empire's subsequent demise may have involved a greater degree of geographical and dynastic accident than is seemingly apparent.
\end{abstract}

Keywords: Spanish colonial trade, «comercio libre», terms of trade, balance of payments, customs revenue, British colonial trade

JEL Classification: N73, N43

\footnotetext{
" Received 05/13/2008. Accepted 07/04/2008. An earlier version of this paper was delivered on 13 March 2008 to the Economic History Seminar of the Universidad Carlos III (Madrid). Thanks are due to the Seminar participants and to two anonymous referees for useful comments and suggestions. Remaining errors and omissions are the author's own.

a 200 University Avenue West, Waterloo, Ontario, Canada N2L 3G1, jcuenca@uwaterloo.ca.
} 


\section{RESUMEN}

Una estimación de la balanza por cuenta corriente de España con sus «Indias» abre nuevas perspectivas al debate sobre los objetivos y resultados de la política comercial española. En pleno apogeo del «comercio libre» en 1784-92, los intereses privados españoles parecen haber extraído mayores flujos financieros del imperio americano que sus homólogos británicos, sobre la base estos últimos de una empresa colonial más amplia. En éste como en otros aspectos, en vísperas de la guerra con Francia el Imperio español parece haber logrado una mayor viabilidad económica de lo que pudiera inferirse de apreciaciones recientes. El subsiguiente colapso del imperio pudo haber obedecido a circunstancias geográficas y dinásticas en mayor medida de lo que pudiera pensarse.

Palabras clave: comercio colonial español, "comercio libre», relaciones de intercambio, balanza de pagos, renta de aduanas, comercio colonial de Gran Bretaña

Despite a generation's work on Spanish colonial trade from 1717 to 1821, the seemingly central task of calculating current values of total imports and exports for the entire period has yet to be attempted. This neglect is all the more intriguing because the 1980s and 1990s witnessed extensive interpretation and debate on the aims and results of Spain's socalled «comercio libre» since $1765^{1}$. Some of the regional studies have supplemented earlier work with trade values and relevant prices ${ }^{2}$. But the regional record remains patchy, and the very thoroughness of this research suggests that much additional evidence susceptible of serial quantification is unlikely to be forthcoming.

For its part the more extensive quantitative work of national scope remained surprisingly close to the primary sources employed. The two systematic attempts to construct a full matrix of import and export values at current prices were explicitly provisional, were restricted to the period 1778-1820, and relied in part on suspect revenue proxies for trade values in $1792-1820^{3}$. García-Baquero's pioneering work on Cadiz's colonial trade in 1717-78 and in 1798-1820 produced a wealth of commodity weights or quantities but no current values ${ }^{4}$. Conversely, Fisher (1981, 1985a, 1985b,

${ }^{1}$ Delgado Ribas et al., eds. (1986); Fontana and Bernal, eds. (1987); Tedde de Lorca (1989); Prados de la Escosura (1993); Llombart (1994); Marichal (1999).

${ }^{2}$ García-Baquero (1972, 1974); Izard (1974); Ortiz de la Tabla (1978); Alonso Álvarez (1986); Delgado Ribas (1989, 1992); Fábregas Roig (2005).

${ }_{3}$ Cuenca Esteban (1981, 1982, 1991); Prados de la Escosura (1993).

${ }^{4}$ García-Baquero (1972, 1976). 
1992) supplied no weights or quantities but export values for 1778-1820, import values at constant prices for 1782-96, and, for Cadiz only, import values at unspecified current prices in 1790-96. García-Baquero (2003) has since addressed some of the more obvious problems raised by both Fisher's work and his own; but the only new figures he provided are total import and export values at constant prices for Cadiz, with no commodity breakdowns for the indicated corrections.

The case for further quantitative work on national trends and cycles is arguably compelling, but the search for accuracy and comprehensiveness should be tempered with considerations of purpose and efficiency. The above mentioned contributions have all been concerned with Spanish domestic issues - most notably with the impact of colonial policy on local economic growth. The primary motivation of the present article stems more broadly from ongoing work on differential access to external wealth by contending European states. The extensive literature on the "fiscal-military state» in the eighteenth-century has focused on the effective mobilization and deployment of available resources ${ }^{5}$. Such matters are major issues in their own right, but they are prone to distract attention from the external mediations on the growth and dependability of the resources in question ${ }^{6}$. The drive for supremacy that reached a climax in the late eighteenth century was fought by Imperial states on a worldwide scale. Of primary importance for such states were those rewards of external involvement able to confer a decisive marginal advantage, not least by supplementing domestic revenue and by helping to finance aggression and defence.

On this particular score the British and Spanish states were leading contenders, but the empirical base for comparative work on the respective external resources has yet to be completed. Unlike their Spanish counterparts, British governments did not rely directly on unilateral transfers from abroad - though such private inflows as the "India drain», and the Irish rents remitted to absentee landlords residing in Britain, may have significantly enlarged the domestic tax base ${ }^{7}$. The largest single source of income for the British state was net customs and excise revenue on worldwide imports, to the tune of 25 per cent of total tax revenue in 1765-80 and 34 per cent by $1803-12^{8}$. One pertinent issue, to be addressed here for the first time, is what proportion of British customs and excise revenue came from duties on colonial trade.

In the Spanish case, a long-standing literature has stressed Bourbon governments' relative dependence on uncertain surplusses from American treasuries and on customs revenue from colonial trade. The Crown's share

\footnotetext{
5 Bowen and González Enciso, eds. (2006); Torres Sánchez, ed. (2007).

6 Bowen (2006); Cuenca-Esteban (2007b).

7 Cuenca-Esteban (2007a).

8 O’Brien (1988); Cuenca-Esteban (2007b).
} 
in bullion imports from America is well documented for much of the eighteenth century and beyond, but comparable work on Spanish revenue from colonial trade remains at the stage of informed guesswork ${ }^{9}$. Pending the unlikely discovery of adequate records beyond cryptic entries in treasury accounts and heterogeneous ship registers, further work in this area must resort to computed trade values and to tax rates on individual commodities. But such sensitive calculations require the closest possible approximation to the tax base on which the revenue was drawn.

To this end, this article builds on a critical analysis of the published figures to construct consistent annual series of Spain's imports from the «Indies» at constant and market prices in 1747-1820. The wider scope and detail of these and other new estimates, and the comparisons they make possible with British external receipts and payments since 1776-78, add new perspectives to recent debate on the aims and results of Spanish commercial policy. At the height of comercio libre in 1784-92, Spain's private commercial interests appear to have drawn larger financial returns from the Indies than did their British counterparts from wider colonial engagement. By virtue of its direct bullion receipts, the colonial purse of the Spanish Treasury also appears to have fared equally well or even better, despite much smaller customs revenue, than did the British Exchequer's. In other substantial respects the volume of Spanish colonial trade was relatively small, and so too must have been the associated domestic benefits. But new analysis of Spain's import gains through 1747-96 does not support Delgado Ribas's assessment despite downward corrections of real growth in 1785-96. By the eve of the French wars, the Spanish empire appears to have become a sounder economic proposition than might be inferred from recent pessimistic views. The empire's subsequent demise may have involved a greater degree of geographical and dynastic accident than is seemingly apparent.

\section{TRENDS AND CYCLES IN SPANISH IMPORTS FROM THE INDIES, 1747-1796}

The 1980s and 1990s witnessed extensive interpretation and debate on the aims and results of Spain's comercio libre legislation since 1765. One of the obvious quantitative issues involved was the growth rate of Spain's colonial exports and imports at constant prices before and after the Reglamento decree of 1778. Fisher's conclusion that Spain's total imports from Spanish America grew more than 15-fold in 1778-96, and that exports were «400 per cent higher in 1782-96 than in 1778», rests on shaky grounds ${ }^{10}$. GarcíaBaquero (2003, pp. 63-78, 192-213) correctly noted that Fisher's import and

\footnotetext{
9 Delgado Ribas (1992); Prados de la Escosura (1993); Marichal (1997).

10 Fisher (1992), p. 17; ibid. (1985a), p. 62.
} 
export figures for his base year of 1778 were grossly understated; that his import values for 1782-89 were "clearly defective»; that the official valuations of tobacco imports that Fisher accepted for 1786-96 were 12.5 times higher than those for 1747-78; and that his trend analysis downplayed the fact that non-bullion imports into Cadiz were officially valued at 1778 prices in 1782-89 and at presumably higher market prices in 1790-96. Fisher's series for 1778-96, and García-Baquero's otherwise acceptable revision for the same period, remain faulty in that neither of these authors corrected for the change of valuation of imports into Cadiz in 1790-96.

The implications of this long-standing omission are roughly conveyed by Figures 1-2. If García-Baquero's current values of non-bullion imports into Cadiz through 1790-96 are re-calculated at constant prices of 1778, they fall by an annual average of 64.2 million reales de vellón or 23 per cent. The new estimates of private import volumes in Figure 1 also exclude independent estimates of tobacco on Crown account (5.5 million per year in 1790-96). Fisher's private, non-bullion import values into all Spanish ports are overstated on two counts: his apparent oversight of a major change in tobacco valuation since 1785 , and his reliance on official values at market prices through 1790-96. The new corrected estimates for Spain in Figure 2, also including minor imports from the Indies by the Compañia Guipuzcoana, by the Compañia de Barcelona, and in the Corunna Correos, together amount to a net annual reduction, through 1785-96, of 154.5 million reales de vellón or 32 per cent. The new figures of private and Crown bullion imports for

\section{FIGURE 1}

CADIZ: PRIVATE NON-BULLION IMPORTS FROM THE INDIES, 1747-1820

(Million reales de vellón at constant prices of 1778).

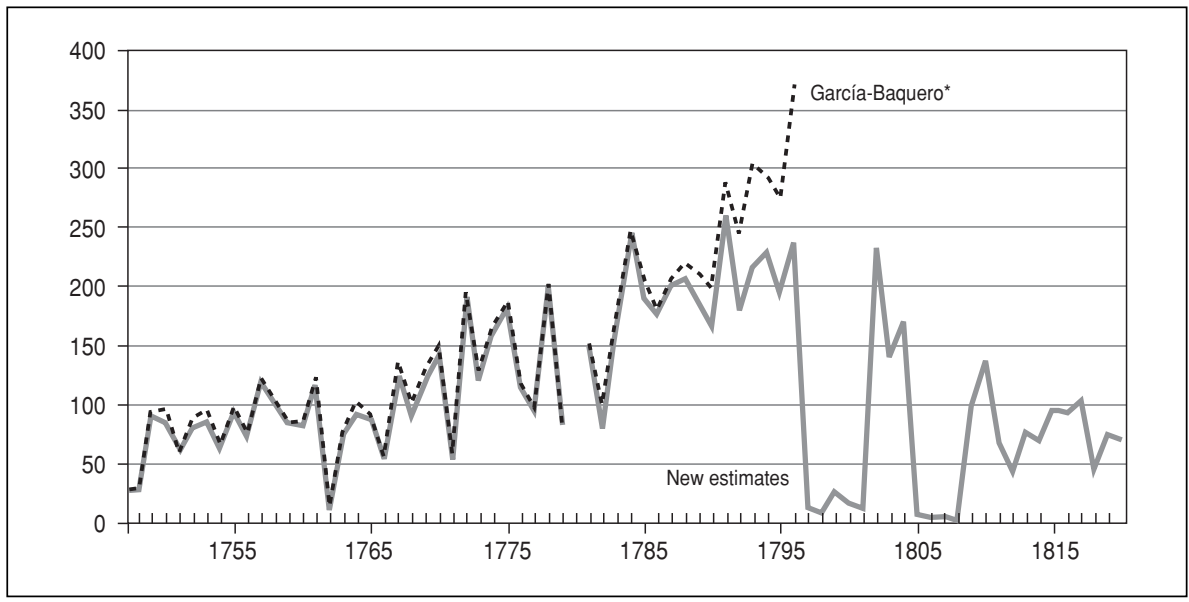

* Crown tobacco included. Market values in 1790-96 only.

Sources and Procedures: See Appendix 2. 
FIGURE 2

SPAIN: PRIVATE NON-BULLION IMPORTS FROM THE INDIES, 1747-1820

(Million reales de vellón at constant prices of 1778).

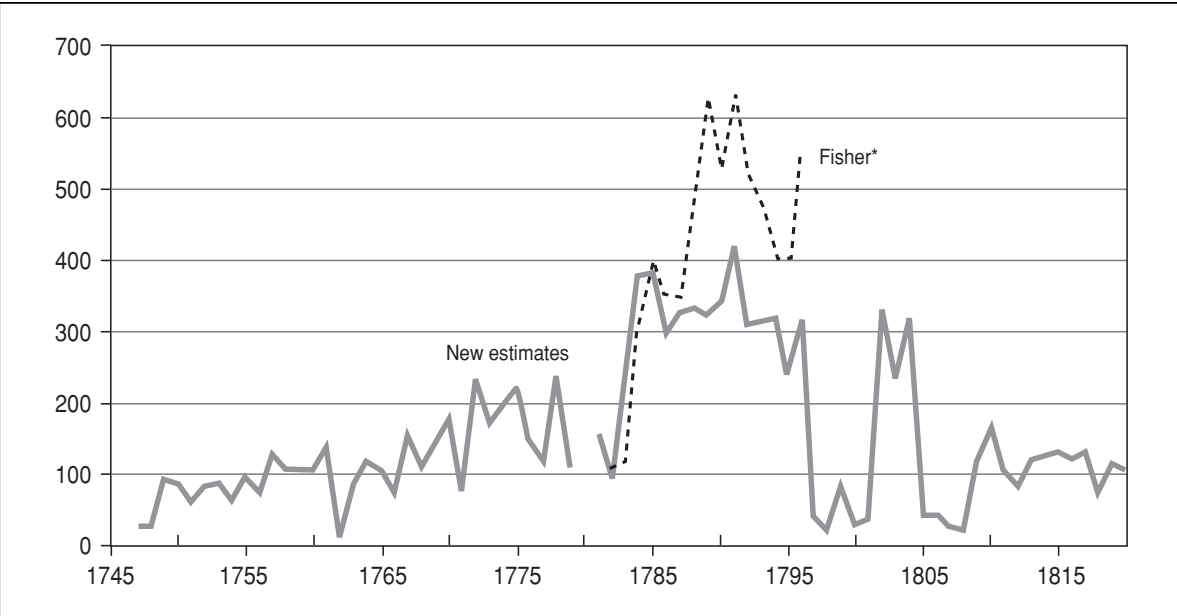

* Company and Correo imports apparently not included.

Sources and Procedures: See Appendix 2.

FIGURE 3

SPAIN: BULLION IMPORTS FROM THE INDIES, 1747-1820

(Million reales de vellón; three-year moving averages).

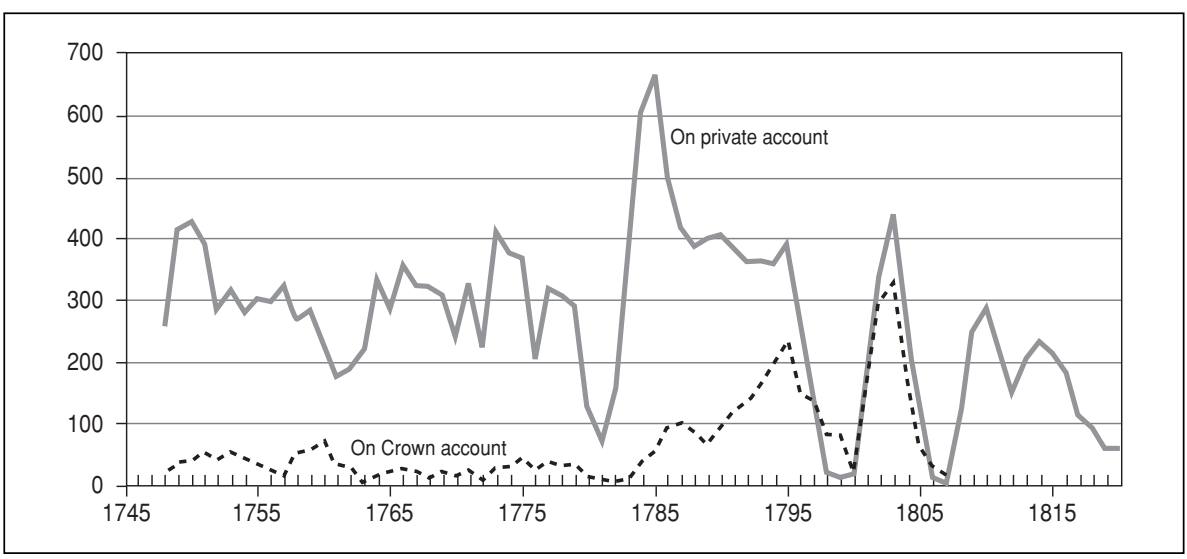

Sources and Procedures: See Appendix 3 and Table 3, line 10.

1747-96 in Figure 3 incorporate comparatively small revisions. All three Figures also include rough new estimates for 1797-1820.

Relevant breakdowns of commodity and bullion flows may be brought to bear on Delgado Ribas's pessimistic assessment of the impact of comer- 
cio libre legislation on Spanish colonial imports. This author drew on Fisher's import figures for 1778-96, and on his own estimates from GarcíaBaquero's import quantities for 1747-77, to suggest that Spain's non-bullion colonial imports on private account grew at lower annual rates in 1782-96 than they did in $1747-78^{11}$. Obviously the broader issues at hand cannot be resolved with trend comparisons alone. The course of Spanish colonial trade was mediated by non-policy influences, some stemming from economic conditions on both sides of the Atlantic and others from the vagaries of warfare and foreign competition. Though the opening up of additional Spanish and colonial ports to Atlantic trade since 1765 was clearly important, the potential role of the alleged fiscal liberalization in promoting trade growth has yet to be ascertained ${ }^{12}$. In any event, systematic comparisons of growth rates in relevant periods provide a vantage platform from which to suggest or to discard apparent causal connections.

The analysis proposed here recognizes that observed discontinuities in import levels are more significant than annual growth rates within arbitrarily specified trends. One basic requirement of trend comparisons is that they should expose any substantial sensitivity to the choice of time ranges. The alternative periodization in Table 1 allows for several starting and ending points for both the early and the later trends, with reference to three-year averages in all but one case. One consideration has been to avoid such atypical or controversial years as 1747 and 1778; another, to concede Delgado Ribas's point that Spain's colonial imports may have substantially benefited from the slave revolts in Saint Domingue since 1789-91. A second requirement of trend analysis is that it be explicitly biased against the proposed conclusion. In the present case, this amounts to comparing the period of highest trend growth during the first three decades with a choice of time ranges around the three thrusts to comercio libre in 1765, in 1778, and in 1789. The early trend in Table 1 starts in 1747-9 or 1752-4 and ends in 1774-6 — the three-year period described by Delgado Ribas (1992, p. 415) as the culmination of the expansive phase of colonial trade.

Even on such adverse terms of comparison, and despite the already specified downward corrections of import growth through 1785-96, between 1775-7 and 1790-2 both Crown and private imports show much higher average growth rates than they do in 1752-3 to 1774-6. Delgado Ribas's finding that bullion and tobacco imports on Crown account grew several times faster since the 1770's is broadly confirmed. But his contention that bullion imports on private account grew half as fast during comercio libre is flatly rejected. Perhaps most significantly, his highly qualified concession that growth in other colonial imports through 1782-96 almost matched previous rates turns out to be far from generous.

\footnotetext{
11 Delgado Ribas (1992), pp. 418-20.

12 For a balanced assessment of the larger issues see Martínez Shaw (1987).
} 
TABLE 1

SPAIN: IMPORTS FROM THE INDIES EXCLUDING COMPANY

AND CORREO TRADE ${ }^{1}, 1747-1796$

(New estimates; commodity import values calculated at 1778 prices)

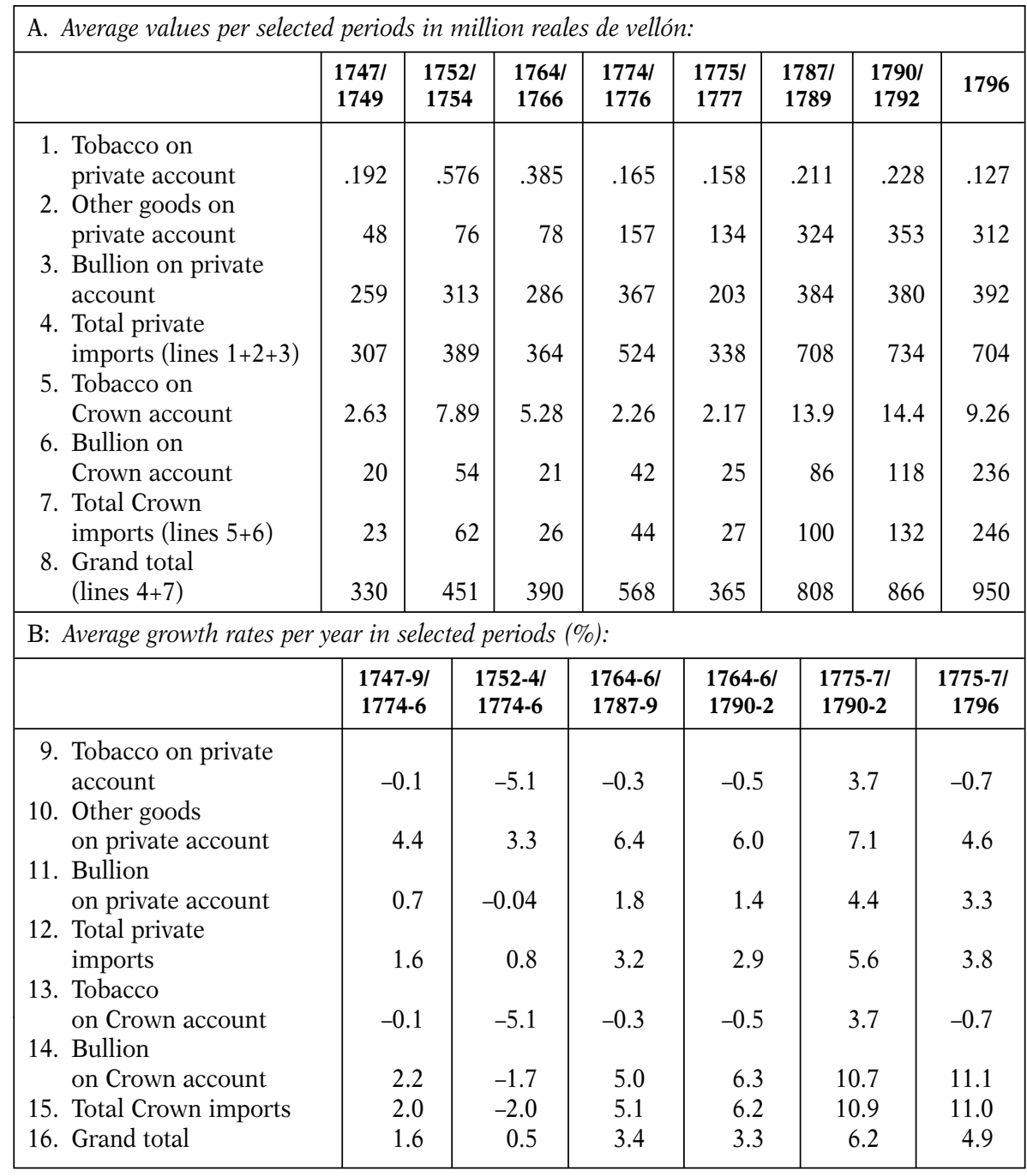

1 As in Appendix Table 2: Compañía Guipuzcoana, Compañía de Barcelona, and Correos Marítimos.

Sources and procedures: Commodity imports as in Appendix Table 2. Bullion imports on private account as in Appendix Table 3. Bullion imports on Crown account as follows: 1747-77: Appendix Table 3, line 3 times the share of García-Baquero's «Real Hacienda» over total "Caudales» (García-Baquero, 1976: II, pp. 264-65); 1782-96: Appendix Table 3, line 3 times the share of Fisher's "crown» over total gold/silver imports into Cadiz (Fisher, 1985a: 74). 


\section{SPAIN'S TERMS OF TRADE WITH THE INDIES, 1752-1820}

The analysis of the preceding section can hardly establish that comercio libre legislation had a favourable impact on Spanish colonial trade; it merely rejects the hypothesis of slower import growth since 1765 or 1778 . Any positive argument, still on strictly quantitative terms and excluding the impact of fiscal policy, must embrace both imports and exports and the relations between the two. Drawing on his figures of colonial trade at constant prices in 1778-96, Fisher (1985b, pp. 60-61) inferred that Spain secured growing imports per unit of exports from the Indies and thus enjoyed favourable terms of trade ${ }^{13}$.

Here again, Fisher's conclusions on relative trade values have been questioned on several counts. Delgado Ribas countered that Fisher's choice of 1778 as a reference year for both import and export growth was inadequate; that the fiscal sources for his trade values are distorted by changes in official assessments in 1778; and that Bernal's figures on risk underwriting point to much weaker export performance through 1779-88 ${ }^{14}$. Perhaps more ominously, García-Baquero (2003, pp. 193-202, 210-16) has specified that Fisher's import and export values for 1778 exclude substantial sums and thus greatly overstate subsequent growth. The implications of these revisions for Spain's terms of trade with the Indies remain inconclusive due to the lack of reliable export values prior to 1782; but Delgado Ribas (1992, p. 421) has tried to reverse Fisher's optimistic assessment by arguing that Spanish exports to the Indies per unit of imports grew less in the last quarter of the eighteenth century than they did in the second.

Consideration of these issues requires theoretical precision and further empirical work. The standard measure of a country's external gains or losses is based on what has come to be called the net barter terms of trade: the ratio of export over net import prices $\left(\mathrm{P}_{\mathrm{X}} / \mathrm{P}_{\mathrm{M}}\right)$. Both Fisher and Delgado Ribas have drawn their conclusions from trends in the gross barter terms of trade - which measure the real import volumes that a country can obtain from foreigners per unit of real export volumes $(\mathrm{M} / \mathrm{X})$. But these two ratios are equal only when commodity trade at current prices is balanced $\left(\mathrm{XP}_{\mathrm{X}}=\right.$ $\mathrm{MP}_{\mathrm{M}}$ ) and long-term capital flows are zero. As will be noted in the following section, all the available evidence on import and export values points to widely different trade balances in relevant reference periods. We may never be able to test the second condition, beyond the conjecture that Spain may have secured growing net inflows through predatory fiscal practices and capital repatriation.

In any event, the gross barter measure will be ignored here in view of reasonable doubts on the growth rate of Spanish export volumes with referen-

\footnotetext{
13 Fisher (1985b), pp. 60-61.

14 Delgado Ribas (1986), pp. 80-2; ibid. (1992), pp. 412-15.
} 
ce to 1778. The upper section of Table 2 compares Fisher's export values at constant prices (lines 1 and 2) with alternative figures in relevant periods (lines 3 to 5). García-Baquero (2003, pp. 210-16) noted that Fisher's total of 75 million reales de vellón for 1778 excludes at least 23 cargoes whose values were not officially assessed; the only alternative figure he found was supplied in a report commissioned by the Cadiz Consulate, to the tune of 364 million reales per year in 1776-78. Fisher's export values for 1782-96 are either similar or moderately lower than those given in contemporary publications. On the fair assumption that the set of cargo inventories used by Fisher may have been incomplete, in lines 3 and 4 his values for 1784-86 are replaced with annual data in García-Baquero's source for 1776-78; and those for 1787-96 with Izard's choice for the same years ${ }^{15}$. For the period $1797-1820$ we have no alternative to Fisher's total export values; his clearly defective figures for 1819-20 have been replaced with rough estimates from García-Baquero's much higher values at constant prices for Cadiz ${ }^{16}$. On the whole, however, García-Baquero's reluctant reservations on the export figures for 1776-78 seem sufficiently sound to compound the stated objections to the gross barter measure as a proxy for Spain's net barter terms of trade.

Unfortunately, the net barter specification poses its own set of problems. Here the primary emphasis is on export and import prices; but the price series for individual commodities must be weighted with the respective quantities, and the available evidence on the export side leaves much to be desired. The two export price indices in the middle section of Table 2 are described in Appendix 5; they separately specify Spanish and foreign goods, with constant weights of 50 and 60 per cent for textile fabrics respectively. The choice of Spanish prices incorporates Delgado Ribas's three series for cotton textiles through 1776-1807 and ten others for representative commodities; but no evidence has been found for silk fabrics, and the constant weights applied are only roughly consistent with the available export data ${ }^{17}$. The foreign goods covered in the second price index include French and British textiles, with documented annual weights, and four other commodities known to have figured prominently in Spanish re-exports to the Indies ${ }^{18}$; it should be noted, however, that the value of Spain's imports from France and Britain together amounted to less than half of the total from foreign countries in $1792^{19}$. For imports from the Indies we are on firmer ground with the proposed Fisher «ideal index» of the prices of 14 commodities (line 10). But the inevitable differences in index construction for imports and for exports introduce an unfathomable source of bias.

\footnotetext{
15 García-Baquero (2003), p. 214; Izard (1974), p. 302.

16 García-Baquero (1972), pp. 236, 239-40.

17 García-Baquero (1974), pp. 285, 291; ibid. (1976), II, pp. 184-85; Balanza... 1792 (1805).

18 Fisher (1981), p. 36.

19 Balanza... 1792 (1803).
} 
TABLE 2

SPAIN: VOLUMES AND PRICES IN PRIVATE TRADE WITH THE INDIES, 1752-1820 (Selected period averages)

\begin{tabular}{|c|c|c|c|c|c|c|c|c|}
\hline & $\begin{array}{l}1752 / \\
1754\end{array}$ & $\begin{array}{l}1765 / \\
1767\end{array}$ & $\begin{array}{l}1776 / \\
1778\end{array}$ & $\begin{array}{l}1782 / \\
1783\end{array}$ & $\begin{array}{l}1784 / \\
1786\end{array}$ & $\begin{array}{l}1788 / \\
1792\end{array}$ & $\begin{array}{l}1793 / \\
1796\end{array}$ & $\begin{array}{l}1815 / \\
1820\end{array}$ \\
\hline \multicolumn{9}{|c|}{ A. Private trade values at constant prices (million reales de vellón) } \\
\hline $\begin{array}{l}\text { 1. Exports FOB (Fisher: } \\
\text { Spanish goods) } \\
\text { 2. Exports FOB (Fisher: } \\
\text { foreign goods) } \\
\text { 3. Exports FOB } \\
\text { (Spanish goods) } \\
\text { 4. Exports FOB } \\
\text { (foreign goods) } \\
\text { 5. Total exports } \\
\text { FOB (lines 3+4) } \\
\text { 6. Non-bullion } \\
\text { imports CIF }\end{array}$ & 76 & 109 & $\begin{array}{c}28^{1} \\
46^{1} \\
138^{2} \\
227^{2} \\
365 \\
166\end{array}$ & $\begin{array}{r}64 \\
60 \\
64 \\
60 \\
125\end{array}$ & $\begin{array}{l}193 \\
217 \\
254 \\
292 \\
546 \\
350\end{array}$ & $\begin{array}{l}184 \\
167 \\
351\end{array}$ & $\begin{array}{l}166 \\
128\end{array}$ & $\begin{array}{l}32 \\
20 \\
49 \\
35 \\
84 \\
111\end{array}$ \\
\hline \multicolumn{9}{|c|}{ B. Price indices $(1776-78=100)$} \\
\hline $\begin{aligned} & \text { 7. } \text { Exports FOB } \\
& \text { (Spanish goods) } \\
& \text { 8. } \text { Exports FOB } \\
& \text { (foreign goods) } \\
& \text { 9. } \text { Total exports FOB } \\
& \text { 10. } \begin{array}{l}\text { Non-bullion } \\
\text { imports CIF }\end{array}\end{aligned}$ & $\begin{array}{l}80 \\
85\end{array}$ & $\begin{array}{l}92 \\
93\end{array}$ & $\begin{array}{l}100 \\
100 \\
100\end{array}$ & $\begin{array}{l}121 \\
114\end{array}$ & $\begin{array}{l}120 \\
117\end{array}$ & $\begin{array}{l}116 \\
110\end{array}$ & $\begin{array}{l}125 \\
133\end{array}$ & $\begin{array}{r}147 \\
\\
83 \\
129\end{array}$ \\
\hline \multicolumn{9}{|c|}{ C. Other indices $(1776-78=100)$} \\
\hline $\begin{array}{l}\text { 11. Net barter } \\
\text { terms of trade } \\
\text { 12. Income terms } \\
\text { of trade }\end{array}$ & 115 & 91 & $\begin{array}{l}100 \\
100\end{array}$ & 79 & $\begin{array}{l}116 \\
216\end{array}$ & 101 & 113 & $\begin{array}{l}90 \\
32\end{array}$ \\
\hline
\end{tabular}

1778 only. and 2 .

2 Conjectural estimates: allocated from total in line 5 with relevant shares calculated from lines 1

Sources and procedures: Lines 1 and 2. 1778, 1782-1796: Fisher, 1981, p. 27. 1797-1820: Fisher, 1992, p. 80. Lines 3 and 4. 1776-78: as in note 2 above. 1782-83: Fisher, 1981, p. 27. 1784-86: García-Baquero, 2003, p. 214. 1787-96: Izard, 1974, p. 302. 1797-1818: Fisher, 1992, p. 80. 1819-20: Domestic and foreign exports from Cadiz in García-Baquero (1972: 236, 239-40) times the respective ratios of Spanish over Cadiz export values in 1816-18 (calculated from Fisher, 1992, p. 80). Line 5. Line $3+$ line 4 . The threeyear average for 1776-78 is that given from evidence in García-Baquero, 2003, p. 212. Line 6. Total private commodity imports as in Appendix Table 2, line 11. The Cadiz component of the Spanish total for 1778 in line 6 equals García-Baquero's «productos» value (2003: 69) minus the estimated value of Crown tobacco imports in 1778. Lines 7-8. See Appendix 5. Line 9. Average of the export price indices in lines 7 and 8, weighted with the respective export values in Table 3, lines 1 and 2 (for 1776-78, 1782-1821), or with the average shares of the same values in 1776-78 (for 1752-75). Line 10. Fisher "ideal index" of the prices of 14 commodities as in Appendix Table 1. The import quantities for 1782-96 were estimated from import values and relevant prices as explained in the text. Line 11. Line 7 over line 10 times 100. Line 12. Line 11 times line 3 over average value of line 3 in 1776-78. 
With these qualifications, the net barter index in line 11 points to mildly favourable terms of trade from 1765-67 to 1793-96, followed by wild fluctuations on a falling trend to 1815-20. The interpretation of this index should be tempered with a word of caution and with two further considerations. In view of the margins of error identified in the preceding paragraph, the upward trend to 1793-96 cannot be regarded as definitive evidence of favourable terms of trade. To be sure, the purchasing power of domestic exports to the Indies, as measured by the income terms of trade (line 12), retains considerable gains to 1796; but it has long been suspected that the available figures of Spanish exports conceal growing proportions of foreign goods and thus incorporate an upward bias. On the positive side, Spanish welfare could have benefited from the progressive specialization, and the external and learning economies, that have been associated with growing exports to the Indies in the late $1780 \mathrm{~s}^{20}$. It has long been recognized that rising (or falling) relative prices do not necessarily amount to real income gains (or losses) if technological change is taken into account. If export prices rise from 100 to 110 per cent, while productivity in the export sector improves in the same proportion, the purchasing power of domestic inputs in terms of overseas products grows by 21 percent (110 times 110 per cent equals 121). One way to capture the key variables involved is to multiply the net barter terms of trade by an index of productivity growth in the export sector, into what is known as the single factoral terms of trade ${ }^{21}$. Unfortunately, in the present state of research the estimation of such complex indicators of Spain's external fortunes in the late eighteenth century confronts insurmountable problems.

\section{SPAIN AND GREAT BRITAIN: CURRENT-ACCOUNT BALANCES WITH THE RESPECTIVE AREAS OF COLONIAL INFLUENCE}

How large were Spain's net inflows from the Indies? How do such inflows compare with those received by competing European nations from their respective areas of colonial influence? A proper answer to the first question requires current trade values at market prices; but only those for imports into Cadiz through 1790-96 were provided by Fisher and by García-Baquero. Most of the new estimates of non-bullion imports in Table 3 have been calculated from price and quantity data as in Appendices 1 and 4; those for legal exports equal the relevant volumes times the respective price indices in Table 2. It must be conceded at once that the new estimates of contraband trade and mercantile profits in

\footnotetext{
20 Tedde de Lorca (1989), pp. 206-09.

21 For an application of this and other concepts to Spanish foreign trade in the nineteenth century see Prados de la Escosura (1988), pp. 213-19.
} 
TABLE 3

SPAIN AND GREAT BRITAIN: PAYMENTS ON CURRENT ACCOUNT WITH THE RESPECTIVE COLONIAL AREAS ${ }^{1}, 1776-1820$

(Period averages of current values in million reales de vellón)

\begin{tabular}{|c|c|c|c|c|c|c|c|c|}
\hline & \multicolumn{2}{|c|}{ 1784-1792 } & \multicolumn{2}{|c|}{ 1793-1796 } & \multicolumn{2}{|c|}{ 1797-1807 } & \multicolumn{2}{|c|}{$1815-1820$} \\
\hline & Spain & Britain & Spain & Britain & Spain & Britain & Spain & Britain \\
\hline $\begin{array}{l}\text { 1. Domestic } \\
\text { exports FOB } \\
\text { 2. +Re-exports FOB } \\
\text { 3. -Non-bullion } \\
\text { imports CIF } \\
\text { 4. +Illegal exports } \\
\text { 5. - -Illegal imports }\end{array}$ & $\begin{array}{r}215 \\
243 \\
\\
-387 \\
147\end{array}$ & $\begin{array}{r}823 \\
173 \\
-1644 \\
-40\end{array}$ & $\begin{array}{r}230 \\
159 \\
-410 \\
49\end{array}$ & $\begin{array}{r}1444 \\
276 \\
-2597 \\
-34\end{array}$ & $\begin{array}{r}91 \\
45 \\
-187 \\
70\end{array}$ & $\begin{array}{r}1826 \\
314 \\
-2954 \\
-35\end{array}$ & $\begin{array}{r}71 \\
27 \\
-188 \\
76\end{array}$ & $\begin{array}{r}1842 \\
290 \\
-3392 \\
-38\end{array}$ \\
\hline $\begin{array}{l}\text { 6. }=\text { Net merchandise } \\
\text { exports } \\
\text { 7. Freight earnings } \\
\text { 8. + Insurance } \\
\text { earnings } \\
\text { 9. +Insured agents' } \\
\text { commissions } \\
\text { 10. +Spanish customs } \\
\text { payments } \\
\text { 11. + } \text { Mercantile } \\
\text { profits }^{2}\end{array}$ & $\begin{array}{l}11 \\
61 \\
72\end{array}$ & $\begin{array}{r}-687 \\
160\end{array}$ & $\begin{array}{r}27 \\
155 \\
46 \\
11 \\
54\end{array}$ & $\begin{array}{r}-911 \\
469\end{array}$ & $\begin{array}{l}20 \\
56\end{array}$ & $\begin{array}{r}-849 \\
489\end{array}$ & $\begin{array}{r}-15 \\
54\end{array}$ & $\begin{array}{r}-1298 \\
522 \\
66\end{array}$ \\
\hline $\begin{array}{l}\text { 12. = Balance } \\
\text { of services } \\
\text { 13. Bullion imports } \\
\text { on private account }\end{array}$ & $\begin{array}{l}257 \\
475\end{array}$ & 317 & $\begin{array}{l}340 \\
366\end{array}$ & 779 & $\begin{array}{l}108 \\
128\end{array}$ & 826 & $\begin{array}{l}135 \\
120\end{array}$ & 779 \\
\hline $\begin{array}{l}\text { 14. Balance of direct } \\
\text { trade \& services } \\
\text { (lines } 6+12) \\
\text { 15. -Payments on } \\
\text { foreign goods } \\
(=\text { line } 2) \\
\text { 16. +Re-exports of } \\
\text { colonial goods }\end{array}$ & $\begin{array}{r}-243 \\
58\end{array}$ & $\begin{array}{r}-173 \\
397\end{array}$ & $\begin{array}{r}-159 \\
62\end{array}$ & $\begin{array}{r}-276 \\
749\end{array}$ & $\begin{array}{r}-45 \\
28\end{array}$ & $\begin{array}{r}-314 \\
902\end{array}$ & $\begin{array}{r}-27 \\
28\end{array}$ & $\begin{array}{r}-519 \\
-290 \\
936\end{array}$ \\
\hline $\begin{array}{l}\text { 17. = Balance of } \\
\text { goods \& services } \\
\text { 18. +Bullion imports } \\
\text { on Crown account } \\
\text { 19. +Tobacco imports } \\
\text { on Crown account } \\
\text { 20. +Net inflows from } \\
\text { the slave trade }\end{array}$ & $\begin{array}{r}290 \\
86 \\
5.6\end{array}$ & -146 & $\begin{array}{r}269 \\
207 \\
4.8\end{array}$ & 341 & $\begin{array}{l}111 \\
120\end{array}$ & 564 & 121 & 128 \\
\hline
\end{tabular}


TABLE 3 (Continued)

\begin{tabular}{|c|c|c|c|c|c|c|c|c|}
\hline & \multicolumn{2}{|c|}{ 1784-1792 } & \multicolumn{2}{|c|}{ 1793-1796 } & \multicolumn{2}{|c|}{ 1797-1807 } & \multicolumn{2}{|c|}{$1815-1820$} \\
\hline & Spain & Britain & Spain & Britain & Spain & Britain & Spain & Britain \\
\hline $\begin{array}{l}\text { 21. +Profits on Irish } \\
\text { exports to British } \\
\text { America } \\
\text { 22. +Net India } \\
\text { transfers } \\
\text { 23. + } \\
\text { Irish rents }\end{array}$ & & $\begin{array}{r}135 \\
63\end{array}$ & & $\begin{array}{r}225 \\
73\end{array}$ & & $\begin{array}{r}135 \\
88\end{array}$ & & $\begin{array}{r}167 \\
98\end{array}$ \\
\hline on current account & 381 & 136 & 481 & 778 & 231 & 896 & 122 & 440 \\
\hline
\end{tabular}

1 Britain's «colonial world» includes her own formal colonies, Ireland, Asia, Africa, and foreign colonies including Spanish America.

2 A residual: lines $12-(7+8+9+10)$. It may include non-service items, such as investment flows and capital repatriation. See the text.

${ }^{3}$ Calculated as line 13 minus line 6: see the text.

4 These balance of payments flows should not be confused with British profits on the slave trade. Detailed calculation in Cuenca Esteban, 2004, p. 45.

${ }^{5}$ Conjectural estimates: one half of the Irish rents seemingly remitted to absentee landlords residing in Britain.

Sources and procedures:

SPAIN: Lines 1 and 2. Calculated from Table 2: line 3 or 4 times line 7 or $8(1778=100)$ over 100. Line 3. Total private commodity imports as in Appendix Table 4, line 10. The Cadiz component of the Spanish total for 1778 equals García-Baquero's "productos» value (2003: 69) minus the estimated value of Crown tobacco imports in 1778. Line 4. Conjectural estimates: lines 1 and 2 times the Gibraltar shares of total British textiles annually exported to Spain and Gibraltar. Current export values estimated from relevant breakdowns in the British Customs Ledgers as in Cuenca Esteban (1997): 890-97. Line 7. See the text. Freight costs on imports calculated as rough estimates of ton equivalents times the relevant British freight rates as in Cuenca Esteban, 2001, pp. 78-79; the resulting totals were scaled up to reach 14\% of current import values in 1785 as estimated by Thomas Southeil: AHN, Estado, legajo 3188 ${ }^{1}$, Exp. 375-3. Freight costs on exports calculated at 17 per cent of current values (AHN, ibid: 25 per cent minus 8 per cent tax revenue). Spanish residents' earnings guessed at 80 per cent of costs. Line 8. See the text. Insurance costs calculated as 80 per cent of current trade values times the British insurance rates as in Cuenca Esteban, 2001, pp. 78-79. Spanish residents' earnings guessed at $80 \%$ of costs. Line 9. Line 1 times 5 per cent: half the rate for 1787 in Fontana Lázaro (1991): 312. Line 10. See the text. Relevant trade values times the respective tax rates in Reglamento... 1778 and in Delgado Ribas, 1986, p. 80. Line 13. Total private bullion imports as in Appendix Table 3, line 9. Line 16. Line 3 times 15 per cent: constant share roughly estimated from the total import value in Balanza... 1792 (1805) and from the export quantities of cocoa, coffee, cotton, Tabasco pepper, and sugar in Balanza... 1792 (1803), times the respective prices as in Appendix Table 1. The calculated share for 1792 is 13.7 per cent. Line 18. 1782-96: Appendix Table 3, line 3 times the share of Fisher's «crown» over total gold/silver imports into Cadiz (Fisher, 1985a: 74). 1797-99, 1802-04: Morineau's total bullion imports (Morineau, 1985: 433-36) minus Appendix Table 3, line 9. 1800-01, 1805-1807: Crown revenue as in Merino, 1987, pp. 65-74: «Indias». Also added "Caudales registrados», "Renta de Correos» in Belloto (1971): 241 (1768-79 only). Line 19. Current value of Crown tobacco imports at market prices as in Appendix Table 1.

GREAT BRITAIN: With minor improvements as in Cuenca Esteban (2004): 41, 45, 48-49. Lines 2123 as in Cuenca-Esteban (2007a): 166. Pounds sterling converted to reales de vellón with exchange rates compiled from Course of the Exchange.

Table 3 inevitably court circular reasoning due to the lack of firm evidence on both counts. The conjectural figures of illegal exports to the Indies in line 4 incorporate annual shares of British textile shipments to Gibraltar; the most that can be said for these figures is that their order of magnitude for 1784-92 is not inconsistent with scattered contemporary evidence for 
the period $1778-87^{22}$. In any event, contraband trade cannot be ignored and the conjectural levels leave sufficient room, as will become apparent, for credible estimates of transport earnings and mercantile profits. The Spanish balance of merchandise trade with the Indies may thus be defined as domestic plus illegal exports minus non-bullion imports retained for domestic consumption. Instead, the «net merchandise exports» in line 6 equal total exports minus total non-bullion imports.

The unconventional arrangement of commodity flows in Table 3 is meant to illustrate the proposed estimation of the Spanish balance of services in direct trade with the Indies. Since the exports FOB (and non-bullion imports CIF) in lines 1-4 are all reckoned at Spanish ports, they respectively exclude (or include) such service items as freight and insurance earnings. The shares of such earnings accruing to Spanish residents and retained at home, together with mercantile profits and customs revenue passed on to American buyers, probably represented major favourable items in the Spanish balance of payments. In the absence of sufficient evidence on mercantile profits in particular, the service balance in line 12 is reckoned as bullion imports on private account (line 13) minus net merchandise exports (line 6). The implicit assumption here is that the extant figures of private bullion remittances to Spain do not include substantial non-service items, such as capital repatriation and investment flows.

In support for this assumption it may be noted that the Spanish service totals in line 12 are seemingly exhausted, in all sub-periods but 1815-20, by rough estimates of the net credits that were probably involved. One common feature of the estimated Spanish earnings on freight and insurance is that they both exceed, per unit of total trade values, their better documented British counterparts. Spanish shipping costs were regarded at the time as extremely onerous ${ }^{23}$. Against this background, the freight differential of 63 per cent implied in Table 3 for the peace years 1784-92 is not implausible; relative diseconomies of scale should also have been involved -particularly in subsequent war periods when Spanish shipping volumes dwindled by well over 50 per cent. The estimated earnings of Spanish shipping insurers are also larger, per unit of total trade values, than those of British underwriters; but much of the difference appears to be explained by the British practice of insuring for only half the cargo values, or not at all during peacetime ${ }^{24}$.

The «customs payments» in line 10 apply to Spain only, because British export taxes were negligible and British import values are estimated at

22 See Bernal (1987), pp. 21-22, and Pearce (2007), pp. 108-110.

23 See Izard (1974), p. 303, note 15.

${ }_{24}$ See note to Table 3, line 8. Analysis and references in Cuenca Esteban (2001), p. 79. The British rate of shipping insurance for 1802 is comparable to those given in AGI, Consulados, legajo 78, no. 84 (blue booklet), Cadiz, 3 August 1802. 
«bond» prices before customs duties ${ }^{25}$. Since Spain's exports to the Indies were valued at private merchants' $\operatorname{costs}^{26}$, presumably excluding commissions and export taxes, the customs revenue paid to the Spanish Treasury would have been passed on to American buyers and should be credited to Spanish residents. A similar consideration applies to the revenue component of the import values CIF at Spanish ports of arrival - which are debited in full in line 3 . The fiscal credits in line 10 have had to be calculated as relevant trade values times the respective tax rates; we may take limited comfort from the close agreement of relevant breakdowns with such contemporary figures for the 1780 s as have been found ${ }^{27}$.

The aggregate Spanish credits on freight, insurance, and customs payments in 1784-92 fall short of the service balance calculated in line 12 by 71.7 million reales de vellón. If this residual is entirely attributed to mercantile profits, it represents an average annual return of 7.2 per cent of Spain's total direct trade with the Indies - a credible rate in view of scattered evidence of wide price differentials across the Atlantic ${ }^{28}$. Subsequent profit rates would have stood at 8.6 per cent in 1793-96 and at 4.1 per cent in 1797-1807. This latter average rate would conceal net losses of 27 per cent during Spain's first naval war with Britain (1797-1801), abnormally large profits of 16 per cent during the truce of Amiens (1802-03), and moderate gains of 5.4 per cent through the second naval war (1804-07). The less credible rate of 15 per cent in 1815-20 is probably exaggerated by significant capital repatriation. When compared to their better documented British counterparts, these Spanish rates of mercantile profits are 50 per cent higher in 1784-92, nearly twice as high in 1793-96, and 41 per cent higher through 1797-1807.

Spain's overall balance of private trade and services with the Indies in line 17 includes private bullion imports, re-exports of foreign goods, and very rough estimates of re- exports of colonial commodities to the rest of the world. One distinctive feature of Spanish colonial trade in 1784-92 would have been that the net service credits (line 12) covered most of the CIF import costs (line 3) and exceeded the FOB value of domestic exports (line 1). By contrast, Britain's service balance with the "colonial world» almost always amounts to less than half the current value of British domestic exports; the financial burden of Britain's merchandise deficits (line 6) was almost equally shared by the net service credits (line 12) and by sizeable reexports of colonial goods to the rest of the world (line 16) -where Britain's comparable strength lay not so much in costly transport charges, or in predatory profit rates, as in larger re-export volumes.

${ }^{25}$ Cuenca Esteban (2001), p. 78.

${ }^{26}$ «Al pie de las fábricas, y si fueren Extranjeros por sus valores corrientes en el Puerto del embarco»: Reglamento... 1778, p. 26.

27 AGS, DGR, 20 remesa, legajos 572, 575.

${ }_{28}$ Tedde de Lorca (1989), p. 202. Prados de la Escosura (1993), p. 268. Bernal (1987), pp. 2122. Also Delgado Ribas (1986), pp. 82-83. 
The remaining items on current account in Table 3 include only those unilateral transfers, and net inflows from multilateral trades, that can be reasonably estimated in the present state of research. The proposed figures of the Spanish Crown's shares of American bullion and tobacco (lines 18 \& 19) presumably include net revenue from import duties at Spanish American ports; the bullion figures alone certainly exceed the Rentas de Indias recorded at the Spanish Treasury ${ }^{29}$. In any event, such Crown receipts as can be documented appear to have stayed well below Britain's net transfers from India (line 22) in most years through 1765-1800.

One striking contrast between unilateral inflows in Spain and Britain is that the former accrued to government and the latter to private interests. In the final analysis, however, all such payments had much in common. Britain's India transfers (line 22) are thought to have been made, for the most part, not in bullion and diamonds but in the form of Indian commodities purchased with Indian revenue. This unrequited «drain» resembles the Spanish Crown's bullion receipts (line 18), and the Irish rental payments to absentee landlords residing in Britain (line 23), in that they all arose from the exercise of military and political power. The net inflows from the British slave trade in line 20 arguably owed much to the cargoes of Indian textiles that only British merchants could supply at cut-throat prices to West African middlemen. Britain's privileged Indian connection would thus have extended its beneficial influence, through its likely impact on the growth of the British slave trade, to the profitable triangular trades across the Atlantic ${ }^{30}$.

Judging from the partial balances on current account in line 24, between the American and French wars (1784-92) Spanish private interests drew larger financial returns from colonial engagement than did their British counterparts. As noted, the apparent relative importance of Spanish transport costs and mercantile profits would be consistent with scattered evidence of wide price differentials across the Atlantic. In other substantive respects Britain's economy and government probably drew much larger benefits, some of which cannot be quantified. The mounting size of British domestic exports, to the tune of four times the Spanish values in most documented years through 1776-96, must have brought substantial differential gains to British producers through its impact on increasing returns and on learning economies ${ }^{31}$. More generally, British trade with the "colonial world» most likely represented a much larger share of national income than that of Spain with the Indies ${ }^{32}$.

29 Annual data on Rentas de Indias in Merino (1987). Note that Marichal's larger totals of Ingresos de Indias include shares of rentas generales and Crown tobacco profits that were levied or made in Spain, and thus do not belong in the Spanish balance of payments: Marichal (1997), pp. $480-83$.

${ }^{30}$ Cuenca Esteban (2004), pp. 44-46.

31 Cuenca Esteban (1997), pp. 898-902.

32 Prados de la Escosura (1988), pp. 77-81. 


\section{CONCLUSION}

This article has qualified, and in some new ways it has aimed to reverse, recent pessimistic views on the course and returns of Spanish colonial trade through 1747-96. At the height of comercio libre in 1784-92, Spain's private interests appear to have drawn larger financial gains from trade with the Indies than did their British counterparts from wider colonial engagement. Further research may fruitfully extend this comparison to those fiscal returns that can be traced back to the respective colonial ventures. On the eve of the French wars in 1788-92, Spain's net customs revenue from colonial trade may have amounted to some 101 million reales de vellón per year ${ }^{33}$. This annual average compares poorly with Britain's net customs revenue of some 170 million reales de vellón per year on imports from the "colonial world» in the same period ${ }^{34}$. The Spanish shortfall would widen from 69 to 88 million if we were to include those domestic revenues that ultimately came from colonial commodities ${ }^{35}$. By virtue of its direct bullion receipts of 95 million per year, however, the colonial purse of the Spanish Treasury might have fared equally well or even better, despite far smaller customs revenue, than did the British Exchequer's. On this as on other scores, by the eve of the French wars the Spanish empire appears to have become a sounder economic proposition than might be inferred from recent pessimistic views.

One implication of this analysis is that the Spanish empire's subsequent demise may have involved a greater degree of geographical and historical chance than is seemingly apparent. The role of accident in Britain's rise to economic and military pre-eminence is seldom sufficiently stressed in the economic history literature. One relevant point here is that Britain's insular location, and a French coastal geography not suitable for harbouring fleets of large warships in the English Channel, helped to hold off foreign armies from Britain's home territory ${ }^{36}$. Unlike Britain, Spain shared with Holland a double exposure on land and sea. The Spanish state's reliance of American bullion rendered its fiscal resources particularly vulnerable to British naval blockade and to French predatory claims on American silver. The compounded impact of external military exposure, and internal economic weak-

${ }_{33}$ Some 54 million from direct colonial exchange and some 47 million from related trades with foreign countries. These fiscal estimates are provisional: note that such revenue breakdowns are hard to disentangle from misleading accounts of «rentas generales» and «libre comercio».

${ }^{34}$ Britain's «colonial world» is defined in Table 3, note 1. Calculated from BNA, Customs 17, vols. 10-13 (customs tables only; tobacco revenue not included).

35 Spanish Royal income on the tobacco monopoly (78 million) and Spanish excise revenue on colonial goods (possibly some 18 million). On the British side, additional revenue collected by the Excise Department on tea, rum, coffee, cocoa, and skins and furs (115 million reales de vellón: compiled and calculated from excise tables in BNA, Customs 17, vols. 10-13; given tobacco revenue not included).

${ }^{36}$ Other seemingly chance factors are listed in Cuenca Esteban (2004), pp. 54-55. 
ness, was at the root of Spain's onslaught on the Mexican economy and on her own colonial trade ${ }^{37}$. Both Britain and Spain may be described as Imperial, «fiscal-military» states ${ }^{38}$. But Spain was held, in no small measure by geographical location and by long-standing dynastic mediations, from retaining its precarious status as a second-rate European power ${ }^{39}$.

\section{APPENDIX 1}

\section{Import prices at Spanish and European ports: constructed annual series, 1747-1820}

The central missing requirement to construct credible annual values of Spanish colonial imports through 1747-1820 is a complete matrix of market prices for a statistically large sample of the commodities involved. The composite price series proposed here have been used to price import quantities; to derive current import values from figures at constant prices; to deflate proxies for import values at current prices; and to calculate Spain's net barter terms of trade with the Indies. A common feature of these tasks is that they all require wholesale market prices at ports of arrival excluding import duties and other taxes. The most comprehensive Spanish sources of such quotations known to this writer are the Correo Mercantil de España y de sus Indias (1792-1808) and the Libros de precios corrientes de la Lonja de corredores de Cádiz (1803-1835). For the 16 years prior to 1792 we also have five relevant series of wholesale prices in Barcelona through 1776-1807 (Delgado Ribas, 1989). For other commodities and time periods we must resort to those prices at non-Spanish European ports that meet the specified requirements of being wholesale and excluding duty. These criteria are satisfied by Posthumus's annual series for Amsterdam, which span the entire eighteenth century, and by the bi-weekly in-bond quotations in the London Price Current and in other British sources since 1779 (Posthumus, 1946; Gayer et al., Supplement, 1953; Tooke, 1824).

The composite price series specified in Appendix Table 1 are the result of systematic testing and critical selection of relevant figures from the indicated sources. The definitive, non-random sample of market prices refers to 14 widely traded American commodities for which Spanish import quantities or values are available. The period $1792-1820$ is almost fully covered by the extensive evidence on market prices in Cadiz; occasional gaps prior to 1804 were filled in with relevant quotations in the Correo Mercantil for

\footnotetext{
37 Marichal (1999). Cuenca Esteban (1982).

38 Torres Sánchez (2007).

39 For an arguably complementary argument stressing structural constraints on Spain's external trade see Cuenca Esteban (1991).
} 
APPENDIX TABLE 1

PRICES AT EUROPEAN PORTS: CONSTRUCTED ANNUAL SERIES, 1747-1820

\begin{tabular}{|c|c|c|c|c|c|}
\hline & Amsterdam & London & Barcelona & Cadiz et $\mathbf{a l}^{1}$ & Cadiz $^{2}$ \\
\hline $\begin{array}{l}\text { Cochineal } \\
\text { (ducados/arroba) }\end{array}$ & $1747-91$ & & & $1792-1802$ & $1803-20$ \\
\hline $\begin{array}{l}\text { Cocoa } \\
\text { (pesos/fanega) }\end{array}$ & $1747-75$ & & 1776-91 & $1792-1798$ & \\
\hline & & & 1799-1801 & $1802-1803$ & $1804-20$ \\
\hline $\begin{array}{l}\text { Coffee } \\
\text { (quartos/libra) }\end{array}$ & $1747-91$ & & & $1792-1803$ & $1804-20$ \\
\hline $\begin{array}{l}\text { Copper } \\
\text { pesos/quintal) }\end{array}$ & $1747-91$ & & & $1792-1803$ & $1804-20$ \\
\hline $\begin{array}{l}\text { Cotton } \\
\text { (pesos/quintal) }\end{array}$ & $1747-75$ & & 1776-91 & $1792-1803$ & $1804-20$ \\
\hline $\begin{array}{l}\text { Dyewood Brasilete } \\
\text { (pesos/quintal) }\end{array}$ & $1747-95$ & & & $1796-1803$ & $1804-20$ \\
\hline $\begin{array}{l}\text { Dyewood Campeche } \\
\text { (pesos/quintal) }\end{array}$ & 1747-89 & $1790-91$ & & $1792-1803$ & $1804-20$ \\
\hline $\begin{array}{l}\text { Hides (reales } \\
\text { plata/35 libras) }\end{array}$ & $1747-91$ & & & $1792-1803$ & $1804-20$ \\
\hline $\begin{array}{l}\text { Indigo (reales } \\
\text { platallibra) }\end{array}$ & $1747-75$ & & $1776-91$ & $1792-1803$ & $1804-20$ \\
\hline $\begin{array}{l}\text { Jesuits' bark (reales } \\
\text { plata/arroba) }\end{array}$ & & $\begin{array}{l}1779-91 \\
1804-20\end{array}$ & & $1792-1803$ & \\
\hline $\begin{array}{l}\text { Pepper, Tabasco } \\
\text { (quartos/libra) }\end{array}$ & $1747-91$ & & & $1792-1803$ & $1804-20$ \\
\hline $\begin{array}{l}\text { Sugar brown } \\
\text { (reales plata/arroba) }\end{array}$ & $1747-81$ & & $\begin{array}{r}1782-91 \\
1799-1801\end{array}$ & $\begin{array}{l}1792-98 \\
1802-03\end{array}$ & $1804-20$ \\
\hline $\begin{array}{l}\text { Sugar white } \\
\quad(\text { reales plata/arroba })\end{array}$ & $1747-81$ & & $\begin{array}{r}1782-91 \\
1799-1801\end{array}$ & $\begin{array}{l}1792-98 \\
1802-03\end{array}$ & 1804-20 \\
\hline $\begin{array}{l}\text { Tobacco (pesos } \\
\text { fuertes/quintal) }\end{array}$ & $1747-81$ & $\begin{array}{r}1782-1805 \\
1819-20\end{array}$ & & & 1806-18 \\
\hline
\end{tabular}

1 Malaga, Corunna, or Barcelona where Cadiz quotations not available in Correo Mercantil.

2 Cadiz only as in AGI (Archivo General de Indias), Consulados, libros 1131, 1134.

3 Also 1778 price as given for «cascarilla o quina» in Reglamento 1778: 1,500 reales de vellón/quintal (or 200 reales de plata/arroba).

Amsterdam prices. Annual averages in Posthumus, 1946, Vol. I: cochineal (Mexican: here reduced by 25 per cent for consistence with calculated averages from Cadiz data; note that Mexican cochineal, a Spanish near monopoly, also paid a duty of 15 per cent upon re-export from Spain); cocoa (Caracas: here reduced by 25 per cent for consistence with calculated averages from Cadiz data; note that Caracas cocoa was a Spanish near monopoly); coffee (Surinam); copper (Norwegian Garcopper 1731-83, Norwegian Trontheim 1784-91); cotton (Smyrna: far closer fit with Spanish series than Surinam prices); yellow wood (here reduced by 25 per cent for consistence with Cadiz quotations for «Palo Campeche»; separate series for «Palo Brasilete» derived with price ratio for Campeche/Brasilete in Reglamento 1778: 60/80); hides (Buenos Aires, per pound of weight: here assumed to weigh 24 pounds per hide for consistence with Cadiz 
quotations per 35-pound cuero; compare Merediz, 1966); indigo (Guatimalo: here reduced by 25 per cent for consistence with calculated averages of añil prices from Cadiz data); pepper (white); sugar (Surinam, presumably brown); sugar (refined); tobacco (Virginia leaves; 1764 price as corrected in Broeze, 1973: 670).

London prices. Compiled from monthly quotations in London Price Current (Jesuits' bark: simple average of "optimum», "second», and "common», 1779-89); in Gayer et al., 1953, microfilmed Supplement (logwood in bond, "Campeachy», 1790-91; Jesuits' bark or quinine yellow in bond, South American, 1790-91 \& 1804-20); and in Tooke, 1824 (tobacco, Virginia 1782-1805 \& 1819-20).

Barcelona prices. Annual data in Delgado Ribas (1989): 41-42, 57-58, 67-69, 80-81: «azúcar» (2 separate price series for brown and white sugar estimated here with Cadiz quotations on Habana azúcar terciada y blanca for 1792); cacao, Caracas (here reduced by 10 per cent for consistence with calculated averages from Cadiz data); añil en flor de Caracas (here reduced by 10 per cent for consistence with calculated averages from Cadiz data); algodón sin pepita (seemingly consistent with "algodón limpio» as for Cadiz 1792-1803). Barcelona prices of dyewood «Palo Campeche» on pp. 75-76 had to be discarded due to lack of agreement with alternative series.

Cadiz prices. Compiled from monthly or quarterly data in Correo Mercantil (1792-1803: Malaga, Corunna, or Barcelona where Cadiz quotations not available), and from monthly data in AGI, Consulados, libros 1131, 1134 (1804-20): cochineal (1792-1802: weighted average of 90 per cent grana fina, 5 per cent granilla, 5 per cent polvo de grana; 1803-20: weighted average of 90 per cent grana superior, 5 per cent corriente, 5 per cent inferior); cocoa (weighted average of 80 per cent cacao Caracas and 20 per cent cacao Guayaquil; note that most of the cocoa produced in Venezuela was exported through La Guayra: Fisher, 1985a, p. 56); coffee («café»); copper (cobre, Perú); cotton (1792-1803: algodón limpio [algodón "sin limpiar» here available for 1792-98 and 1802-03 only]; 1804-20: simple average of algodón varita, Girón, Caracas); dyewood Brasilete (Palo Brasilete); dyewood Campeche (Palo Campeche); hides (cueros, Buenos Aires); indigo (simple average of quotations for añil flor, sobresaliente, corte); Jesuits' bark (cascarilla or quina; see also note 1 above); pepper (Tabasco); sugar, brown and white (azúcar Habana, terciada and blanca); tobacco (Tabaco Virginia in Cadiz).

Weights and measures. Fanega $=110$ libras. Quintal $=100$ libras. Arroba $=25$ libras. The Amsterdam pound was taken to weigh 1.089 English pounds.

Monetary conversions (Spanish). Real de vellón = 34 maravedís de vellón. Peso de cambio $=8$ reales de plata $=128$ quartos $=15$ reales and 2 maravedís de vellón. Peso fuerte $=20$ reales de vellón. Ducado de cambio $=20.76103$ reales de vellón (Marién y Arróspide, 1789). Catalan dinero $=9.067$ maravedís; 42 Catalan dineros $=1$ real de plata (Ardoin et al., 1845-6: I, 74, 335). The Catalan "peso sencillo» was assumed to equal 1 peso de cambio.

Rates of international exchange: Annual rates calculated from the first monthly quotations in the bi-weekly issues of the Course of the Exchange (London on Cadiz and London on Amsterdam). Adjustments for Amsterdam bank quotations and occasional missing rates from relevant data in Posthumus, 1946: I, 610-12, 653-55.

Malaga, Corunna, and Barcelona. For the earlier period 1776-91, four of Delgado Ribas's five annual series of relevant wholesale prices in Barcelona (1776-1807) were judged sufficiently close to comparable Cadiz data for the 1790 s to warrant their adoption with two minor scale adjustments. The calculated market values of the four commodities covered with Barcelona prices together account, on average, for 60 per cent of total import values. Remaining blanks in 1776-91, and through 1747-75 for all 14 commodities, were filled in with a choice of Dutch and British prices converted to Spanish currency with international exchange rates. The Amsterdam prices of Mexican cochineal, Caracas cocoa, and Guatimalo indigo, all three of which were Spanish near monopolies, had to be scaled down by 25 per cent to match average levels in Cadiz or in Barcelona; these adjustments presumably account for mercantile profits, transport costs to Amsterdam, and a Spanish export tax on cochineal. Elsewhere the Dutch and British price series were found tolerably consistent with their Spanish counterparts in commonly documented peace periods through 1776-1820. 
Such broad consistence between Spanish and Dutch or British prices was to be expected for homogeneous, widely traded staples and raw materials with common origins in the Americas and the Far East. But we can hardly expect that international exchange rates remained close enough to purchasing-power parity, and merchants' arbitrage sufficiently efficient, to bring short-term fluctuations in line during war periods in particular.

\section{APPENDIX 2}

\section{Spain: Private non-bullion imports from the Indies at 1778 prices, 1747-1818}

For total imports into Cadiz at constant prices in 1782-96 we have no published quantities, only Fisher's annual values by commodities for 178289 (Appendix Table 2, line 1) and García-Baquero's corrected totals for Cadiz only in the same years (line 3). Fisher's total import values into Cadiz must be discarded because his relatively large figures for Crown and private tobacco are grossly overstated. Fisher (1885a, p. 43) reported that, in 1788-9, two large consignments of tobacco from New Orleans were officially valued at 40 reales de vellón per pound; he apparently overlooked that this was a single and major exception to the general practice of pricing import commodities at the fixed rates that were published in the Reglamento y aranceles reales para el comercio libre de España a Indias (12 October 1778). As noted by García-Baquero (2003, pp. 73-5), since 1785, tobacco imports were officially valued at 12.5 times above the constant rate used in the Cadiz customs from 1747 to 1778 (official rates in Reglamento, 1778, Arancel Segundo; and in García-Baquero, 1976, II, pp. 271-75).

Accordingly, García-Baquero replaced the official tobacco values for 1785-9 with alternative calculations at 1778 prices to obtain consistent totals of import values into Cadiz. One further reason to adopt GarcíaBaquero's figures is that they include the years 1779-81 and were newly compiled, up to 1789 , from more comprehensive sources than those used by Fisher (García-Baquero, 2003, pp. 64-5, 67-8). The "private commodity imports» into Cadiz for 1782-89 in Appendix Table 2 (line 4) are the result of subtracting similar re-calculations of Fisher's values of Crown tobacco values at the Reglamento rates from García-Baquero's corrected totals. For 1790-96, Fisher's current values for Cadiz by commodities, excluding «wood» and «others» (Fisher, 1985a, pp. 74-75), were divided by the respective market prices as in Appendix Table 1 (or by Fisher's given official rates for tobacco only: 1985a, p. 43); the resulting import quantities were then multiplied by the respective Reglamento rates to obtain the real import volumes in line 5. The 1790-96 totals for Cadiz in line 6 are the result of applying the implicit ratios of market over constant values to García- 


\section{APPENDIX TABLE 2 \\ SPAIN: NON-BULLION IMPORTS \\ FROM THE INDIES AT 1778 PRICES, 1747-1818}

(New estimates unless otherwise stated; period averages in thousand reales de vellón)

\begin{tabular}{|c|c|c|c|c|}
\hline & $\begin{array}{l}\text { 1747-50, } \\
1752-77\end{array}$ & $1782-89$ & $1790-96$ & $\begin{array}{c}1798-11 \\
1815-18\end{array}$ \\
\hline \multicolumn{5}{|c|}{ A. Total commodity imports (private + Crown) } \\
\hline $\begin{array}{l}\text { 1. Cadiz (Fisher) } \\
\text { 2. Other Spanish ports (Fisher) } \\
\text { 3. Cadiz (García-Baquero, 2003) }\end{array}$ & 98801 & $\begin{array}{l}234379 \\
108731 \\
192891\end{array}$ & 109183 & \\
\hline \multicolumn{5}{|l|}{ B. Private commodity imports } \\
\hline $\begin{array}{l}\text { 4. Cadiz excluding Crown tobacco } \\
\text { 5. Cadiz (14 commodities) } \\
\text { 6. Cadiz (all commodities) } \\
\text { 7. Compañía Guipuzcoana } \\
\text { 8. Cía de Barcelona (1758-77) } \\
\text { 9. Correos marítimos (Corunna) } \\
\text { 10. Other Spanish ports } \\
\text { 11. Spain (lines } 6+7+8+9+10)\end{array}$ & $\begin{array}{r}94041 \\
78975 \\
94041 \\
9810 \\
1841 \\
2751 \\
1436 \\
109879\end{array}$ & $\begin{array}{r}182492 \\
148206 \\
182492 \\
1878\end{array}$ & $\begin{array}{l}173847 \\
210509\end{array}$ & $\begin{array}{r}41358 \\
110219\end{array}$ \\
\hline
\end{tabular}

Sources and procedures: Line 1. Fisher (1985a): total imports into Cadiz (p. 75) plus estimated values of Crown tobacco imports in 1784 and 1785 (see ibid. pp. 56-57) minus total gold/silver into Cadiz (ibid, p. 74). Line 2. Calculated from values at 1778 prices in Fisher (1985a): $65-73$ (gold/silver into Barcelona excluded). Line 3. García-Baquero (2003): 68-70 (1747-85: «Productos») and 76 (1786-89: «Géneros B»). Line 4. 1747-50, 1754-77: Line 3 minus «Real Hacienda: Productos» (García-Baquero, 1976: II, 264-65) times 20. 1751: as in line 3. 1752-53, 1782-89: Line 3 minus independent estimates of Crown tobacco values at 1778 prices. Line 5. Estimated total value of the 14 commodities in Appendix Table 1 at 1778 prices: see the text. Line 6. 1747-77: as in line 4. 1782-89: Line 3 minus estimated value of Crown tobacco at 1778 prices. 1790-96: see the text. 1798-1811, 1815-18: line 5 times 1.05 (line 4 over line 5 in 1786 89). 1797, 1812-14, 1819-20: Cuenca Esteban, 1981: 400-01 (Cadiz). Line 7. Import quantities of cocoa, hides and tobacco through 1757-85 (García-Baquero, 1976: II, 241-47fn.; Hussey, 1934: 305-18), times the respective 1778 prices in Reglamento (1778), plus 5 per cent. Line 8. "Valor Productos» in Oliva Melgar (1987): 319 (1758-77 only: see ibid, p. 211). Line 9. «Frete s/ carga total de particulares» in Belloto (1971): 241 (1768-79), converted to import values into Corunna with algorithm in Alonso Alvarez (1986): 54, and deflated with an index $(1778=100$ per cent $)$ of hides prices as in Appendix Table 1. Line 10. 1747-65: zero. 1766-77: 3 per cent of line 6 (guess from García-Baquero's inference from 1778 data: 2003: 66-67). 1782-96: as in line 2. 1797-1820: Cuenca Esteban (1981): 400-01: «7 other ports» plus Barcelona.

Baquero's revised current values excluding independently estimated values of Crown tobacco.

The remaining procedures outlined in Appendix Table 2 are relatively straightforward. García-Baquero's official totals of private non-bullion imports for 1747-77 (line 3) were judged sufficiently close to independent calculations, from a large sample of import quantities excluding Crown tobacco (line 5), to warrant their adoption for this period. Also accepted were Fisher's non-bullion import values at 1778 prices for chartered Spanish ports other than Cadiz in 1782-96; these figures do not include tobacco and are therefore free from the inconsistent valuation found in 
Fisher's totals for Cadiz. The import values for «other Spanish ports» in subsequent years (line 10) are uncertain estimates from the proceeds of the periage and avería duties in Barcelona and elsewhere; it is rewarding to note, in any event, that similar estimates from the proceeds of Consulado Antiguo in Cadiz are remarkably close to independently calculated values, at the 1778 rates, from García-Baquero's import quantities for the same port in 1798-11 and in 1815-18 (García-Baquero, 1972). Lines 7 to 9 incorporate Oliva Melgar's commodity import values for the Compañía de Comercio de Barcelona a Indias (1758-85) and new estimates at 1778 prices of goods imported by the Compañia Guipuzcoana (1757-85) and by the Correos maritimos de Coruña (1768-79). The annual private totals underlying line 11 are given in Appendix Table 5.

\section{APPENDIX 3}

\section{Spain: Bullion remittances from the Indies, 1747-1818}

The available series of Spanish bullion imports also require additional work. Here García-Baquero's new figures should have sufficed, because they incorporate more comprehensive sources that those used by Fisher up to 1789; García-Baquero's new totals are also claimed to be an improvement over Morineau's rendition from Dutch and Spanish publications. Unfortunately, neither author has provided the key distinction between private and Crown remittances (García-Baquero, 2003, pp. 54-7, 64-5, 67-8; Morineau's relevant breakdowns are cryptic and fragmentary: 1985, pp. 418-19). The breakdowns for Cadiz in Appendix Table 3 were estimated from García-Baquero's new totals, with calculated shares from his earlier figures for 1747-77, and from Fisher's own for 1782-96. Also included in Appendix Table 3 are Fisher's private bullion imports into Barcelona in 1782-96 (line 5), Morineau's totals for the same port through 1797-1804, and uncertain estimates from the proceeds of the avería duty in Corunna in 1786-1820 and in three other Spanish ports through 1791-1820 (line 8). Here again the resulting totals were compounded with estimated bullion imports by the Compañia de Barcelona (1758-85) and in the Correos maritimos de Coruña (1768-79). The annual private totals underlying line 9 are given in Appendix Table 5. 


\section{APPENDIX TABLE 3}

SPAIN: BULLION REMITTANCES FROM THE INDIES, 1747-1818

(New estimates unless otherwise stated; period averages in thousand reales de vellón)

\begin{tabular}{|c|c|c|c|c|}
\hline & $\begin{array}{l}\text { 1747-50, } \\
1752-77\end{array}$ & $1782-89$ & $1790-96$ & $\begin{array}{r}1798-11 \\
1815-18\end{array}$ \\
\hline \multicolumn{5}{|c|}{ A. Total gold and silver (private + Crown) } \\
\hline 1. Spain (Fisher, 1985) & & 326125 & 508514 & \\
\hline 2. Cadiz (Fisher, 1985) & & 309215 & 484218 & \\
\hline 3. Cadiz (García-Baquero, 2003) & 318612 & 442881 & 484218 & \\
\hline \multicolumn{5}{|c|}{ B. Gold and silver (private remittances only) } \\
\hline 4. Cadiz & 289150 & 390220 & 315251 & 133182 \\
\hline 5. Barcelona (Fisher, 1985) & & 16909 & 24295 & \\
\hline 6. Cía de Barcelona (1758-77) & 607 & 15 & & \\
\hline 7. Correos marítimos (Corunna) & 3101 & & & \\
\hline 8. Other Spanish ports & & 24222 & 32640 & 22701 \\
\hline 9. Spain (lines $4+5+6+7+8$ ) & 292859 & 431367 & 372188 & 155884 \\
\hline
\end{tabular}

Sources and procedures: Line 1. Fisher (1985a): 73-74. Line 2. Fisher (1985a): 74. Line 3. GarcíaBaquero (2003): 68-70 (1747-85) and p. 76 (1786-96): «Caudales». Line 4. 1747-77: line 3 times the share of García-Baquero's "particulares» over total «Caudales» (García-Baquero, 1976: II, pp. 264-65). 1782-96: line 3 times the share of Fisher's ["private» + "soldadas»] over total gold/silver imports into Cadiz (Fisher, 1985a: 74). 1797-1820: proceeds of the duty "Consulado Antiguo» (0.5 per cent) on gold and silver imported on private account into Cadiz, times 200 (as in Cuenca Esteban, 1978: Table 8b). Line 5. Fisher (1985a): 73 («soldadas» plus «private»). Line 6. «Valor Caudales» in Oliva Melgar (1987): 319 (1758-77 only: see ibid, p. 211). Line 7. "Caudales registrados»: "Renta de particulares» in Belloto (1971): 241 (1768-79). Line 8. Proceeds of the «avería» duty (0.5 per cent) on gold and silver imported on private account into Alicante, Malaga, Santander (1791-1820), and Corunna (1786-1820) times 200 (sources and procedures in Cuenca Esteban, 1978: Chapter 1). Also added Morineau's bullion imports into Barcelona in 1797-1804 only (Morineau, 1985: 433-36).

\section{APPENDIX 4}

\section{Spain: Private non-bullion imports from the Indies at market prices, 1747-1818}

The only such figures published so far are those for Cadiz through 1790-96. Here again, Fisher provided no import quantities and his total import values at market prices are grossly overstated: it has been verified that GarcíaBaquero's much lower figures, incorporating his corrected values of tobacco imports, are consistent with independent re-calculations of Fisher's commodity breakdowns with current prices as in Appendix Table 1. Accordingly, the «private commodity imports» into Cadiz in Appendix Table 4 (line 3) are the result of subtracting similar re-calculations of Fisher's values of Crown tobacco from García-Baquero's corrected totals in line 2. For the earlier period 178289 we must resort, as a point of departure, to the import values at constant prices in Appendix Table 2. For Cadiz, Fisher's constant-price values for 14 major 
commodities were divided by the respective Reglamento rates (or by Fisher's given official rates for tobacco only: 1985a, p. 43); the resulting estimates of import quantities were multiplied by relevant market prices as in Appendix Table 1. The total current imports in Appendix Table 4, line 5 were then derived from relevant ratios in Appendix Tables 2 and 4 as indicated in the Table notes. For «other Spanish ports» through 1782-96 (line 9), Fisher's values were reflated with the ratios of Cadiz's current over constant-price import values in the same years. Similar procedures were applied to the periods 1747-77 and 1797-20; but here there was no need to estimate the quantities of 14 commodities imported into Cadiz because most of these were provided by GarcíaBaquero $(1972,1976)$. Lines 6 to 8 incorporate Belloto's proxies for imports in the Correos maritimos de Coruña (1768-79) and new estimates at market prices of Oliva Melgar's commodity import values for the Compañía de Comercio

\section{APPENDIX TABLE 4 \\ SPAIN: NON-BULLION IMPORTS FROM THE INDIES AT MARKET PRICES, 1747-1818 \\ (New estimates unless otherwise stated; period averages in thousand reales de vellón)}

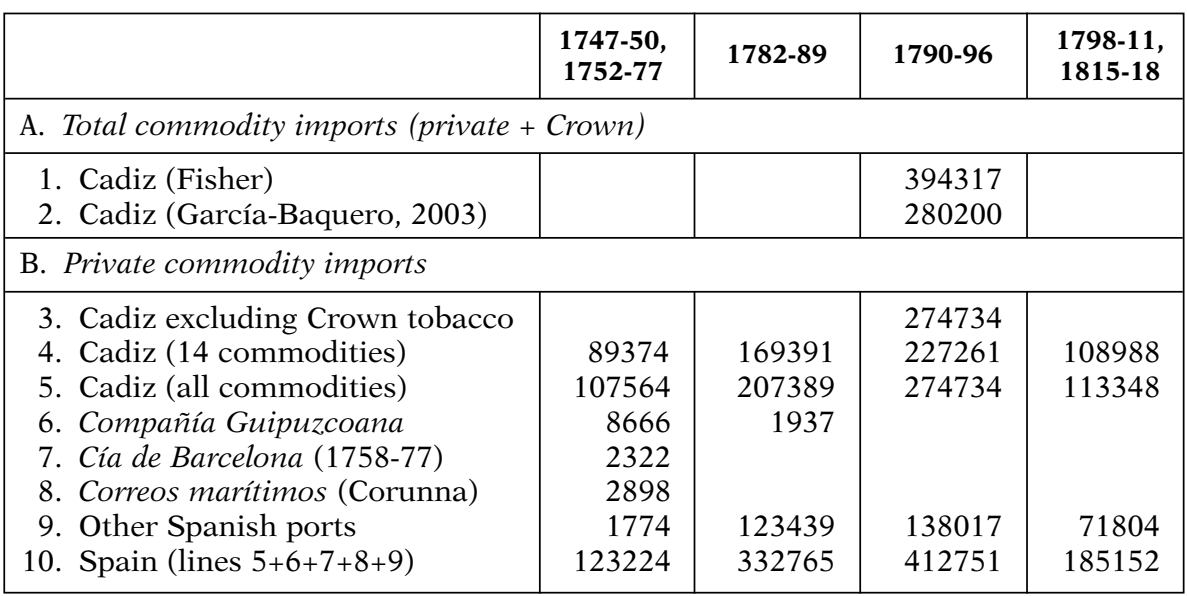

Sources and procedures: Line 1. Fisher (1985a): 74-75: total imports minus total gold/silver. Line 2. García-Baquero (2003): 76, "Géneros B». Line 3. Line 2 minus estimated value of Crown tobacco at market prices as in Appendix Table 1. Line 4. Estimated total value of 14 commodities at market prices as in Appendix Table 1. Line 5. 1747-77, 1782-89: Line 4 plus [(line 6 - line 5 in Appendix Table 2) over line 5 in Appendix Table 2 times line 4 in Appendix Table 4]. 1790-96: line 2 minus independently estimated values of Crown tobacco at market prices. 1797-1820: line 4 times 1.04 (line 3 over line 4 in 1790-96). Line 6. Import quantities of cocoa, hides and tobacco through 1757-85 (García-Baquero, 1976: II, 241-47 fn.; Hussey, 1934: 305-18), times the respective market prices as in Appendix Table 1, plus 5 per cent. Line 7. «Valor Productos» in Oliva Melgar (1987): 319 (1758-77 only: see ibid, p. 211), reflated with a weighted index (1778 = 100 per cent) of cocoa and hides prices as in Appendix Table 1. Line 8. "Frete s/ carga total de particulares» in Belloto (1971), p. 241 (1768-79), converted to import values into Corunna with ad hoc algorithm in Alonso Alvarez (1986): 54. Line 9. 1747-65: zero. 1766-77: 3 per cent of line 5 (guess from García-Baquero's inference from 1778 data: 2003, pp. 66-67). 1782-1820: line 10 in Appendix Table 2 over line 6 in Appendix Table 2 times line 5 in Appendix Table 4. 
de Barcelona a Indias (1758-85) and of goods imported by the Compañia Guipuzcoana (1757-85). The annual private totals underlying line 10 are given in Appendix Table 5.

\section{APPENDIX TABLE 5}

SPAIN: PRIVATE IMPORTS FROM THE INDIES, 1747-1820

(Estimated values in million reales de vellón)

\begin{tabular}{|c|c|c|c|c|c|c|c|}
\hline Year & $\begin{array}{c}\text { At constant } \\
\text { prices }\end{array}$ & $\begin{array}{c}\text { At current } \\
\text { prices }\end{array}$ & Bullion & Year & $\begin{array}{c}\text { At constant } \\
\text { prices }\end{array}$ & $\begin{array}{l}\text { At current } \\
\text { prices }\end{array}$ & Bullion \\
\hline 1747 & 25.798 & 24.319 & 110.996 & 1784 & 377.577 & 426.365 & 803.526 \\
\hline 1748 & 27.649 & 20.964 & 103.310 & 1785 & 379.388 & 434.448 & 682.500 \\
\hline 1749 & 89.848 & 86.223 & 562.586 & 1786 & 294.088 & 335.754 & 493.624 \\
\hline 1750 & 83.692 & 78.043 & 567.790 & 1787 & 321.872 & 295.335 & 316.289 \\
\hline 1751 & 58.247 & 54.316 & 142.147 & 1788 & 329.183 & 381.625 & 433.770 \\
\hline 1752 & 79.770 & 74.386 & 451.243 & 1789 & 321.112 & 361.761 & 402.486 \\
\hline 1753 & 85.051 & 79.311 & 256.056 & 1790 & 337.242 & 390.892 & 353.958 \\
\hline 1754 & 62.124 & 53.027 & 232.508 & 1791 & 415.044 & 448.887 & 443.711 \\
\hline 1755 & 93.917 & 108.313 & 352.903 & 1792 & 307.629 & 407.764 & 342.641 \\
\hline 1756 & 72.220 & 77.379 & 313.813 & 1793 & 310.871 & 433.384 & 300.232 \\
\hline 1757 & 123.193 & 139.840 & 223.651 & 1794 & 315.298 & 403.406 & 443.400 \\
\hline 1758 & 102.843 & 124.214 & 428.405 & 1795 & 239.768 & 329.680 & 329.411 \\
\hline 1759 & 102.416 & 106.709 & 156.605 & 1796 & 311.992 & 475.251 & 391.963 \\
\hline 1760 & 103.806 & 117.279 & 259.866 & 1797 & 32.801 & 49.965 & 14.494 \\
\hline 1761 & 132.949 & 145.105 & 264.635 & 1798 & 20.699 & 43.373 & 2.917 \\
\hline 1762 & 11.256 & 12.595 & 5.139 & 1799 & 81.557 & 165.186 & 35.174 \\
\hline 1763 & 83.137 & 80.641 & 294.002 & 1800 & 27.995 & 49.489 & 3.398 \\
\hline 1764 & 113.482 & 113.898 & 352.250 & 1801 & 33.765 & 57.366 & 7.721 \\
\hline 1765 & 102.875 & 106.448 & 339.320 & 1802 & 324.734 & 545.369 & 559.393 \\
\hline 1766 & 72.545 & 76.506 & 166.515 & 1803 & 230.739 & 384.736 & 442.443 \\
\hline 1767 & 151.238 & 177.510 & 553.170 & 1804 & 312.669 & 567.760 & 305.626 \\
\hline 1768 & 107.741 & 131.762 & 241.113 & 1805 & 39.303 & 68.059 & 23.581 \\
\hline 1769 & 142.105 & 198.218 & 163.592 & 1806 & 40.325 & 67.735 & 5.922 \\
\hline 1770 & 175.935 & 234.007 & 514.578 & 1807 & 26.423 & 54.904 & 5.059 \\
\hline 1771 & 75.549 & 90.946 & 41.529 & 1808 & 19.105 & 39.126 & 3.740 \\
\hline 1772 & 228.655 & 316.798 & 411.505 & 1809 & 114.484 & 166.941 & 331.368 \\
\hline 1773 & 170.044 & 196.899 & 214.925 & 1810 & 160.350 & 215.861 & 401.991 \\
\hline 1774 & 196.243 & 197.526 & 593.684 & 1811 & 101.748 & 131.939 & 121.998 \\
\hline 1775 & 218.294 & 237.820 & 310.892 & 1812 & 81.450 & 105.618 & 133.953 \\
\hline 1776 & 146.137 & 135.099 & 197.642 & 1813 & 117.719 & 152.649 & 195.469 \\
\hline 1777 & 115.879 & 154.959 & 101.557 & 1814 & 122.686 & 159.090 & 277.672 \\
\hline 1778 & 234.623 & 234.623 & 647.082 & 1815 & 128.771 & 223.562 & 216.457 \\
\hline 1779 & 108.494 & 110.347 & 167.963 & 1816 & 120.773 & 202.215 & 151.788 \\
\hline 1780 & & & 51.925 & 1817 & 128.089 & 229.698 & 173.517 \\
\hline 1781 & 154.691 & 297.040 & 156.045 & 1818 & 72.431 & 119.431 & 13.832 \\
\hline 1782 & 94.593 & 167.088 & 4.201 & 1819 & 110.897 & 182.857 & 92.236 \\
\hline 1783 & 227.006 & 259.751 & 314.542 & 1820 & 104.459 & 172.242 & 71.566 \\
\hline
\end{tabular}

Sources and procedures: See Appendix Tables 2, 3, and 4. 


\section{APPENDIX 5}

\section{Spain: Price indices of exports and re-exports, 1747-1820}

The price index of Spanish domestic exports FOB in Table 2 (line 7) is a weighted average of a textile price index (50 per cent) and the prices of seven other Spanish commodities (50 per cent), with a choice of commodities and constant weights as consistent as possible with export data in García-Baquero (1974, pp. 285, 291), in García-Baquero (1976, II, pp. 18485), and in Balanza... 1792 (1805). The textile prices include those for three cotton fabrics in most years through 1776-1807 (Delgado Ribas, 1989, pp. 137-38, 142-43, 146-47); Hamilton's prices of estameña, lienzo, and paño blanco in 1752-1800 (Hamilton, 1988 [1947], pp. 297-308); and the subindex of French textile prices in Table 2, line 8 (1800-20). The seven other Spanish goods include aguardiente (15 per cent), almonds (5 per cent), cinnamon ( 5 per cent), olive oil (5 per cent), paper (5 per cent), wine (10 per cent), and wax (5 per cent): price data to 1791 in Hamilton, 1988 [1947], pp. 297-308; since 1792 compiled and processed from sources in Appendix Table 1, "Cadiz prices».

The price index of re-exports FOB in Table 2 (line 8) is a weighted average of a textile price index (60 per cent) and the prices of four other foreign commodities (40 per cent). The textile index includes the French prices of étoffes de laine, filasses de lin, and "toiles» from 1752 to 1789 (Labrousse, 1933, II, pp. 321-22, 331-33); a price index of French textiles exported to Spain through 1797-1820 (Cuenca Esteban, 1987, pp. 227, 231, 246-47); and unit values of British linen, woollen, and cotton fabrics exported to Spain and Gibraltar in 1772-1820 (weighted estimates as in Cuenca Esteban, 1994, 1999). Other foreign goods known to have figured prominently in Spanish re-exports to the Indies include Portuguese cod, United States flour, and Dutch spices (Fisher, 1981, p. 36); the trends involved have been proxied with price series for salted sardines and fish (Hamilton, 1988 [1947], pp. 297-308; Correo Mercantil: 1792-1803; AGI, Consulados, libros 1131, 1134: 1804-20); for wheat flour (Bezanson et al., 1936, p. 80; Bezanson et al., 1951, pp. 332-42; Beveridge, 1939, pp. 574-75); and for cinnamon and pepper (British and Dutch evidence as in Cuenca Esteban, 2001, p. 75; Gayer et al., 1953, Supplement, p. 670; Tooke, 1824, IV, pp. 42-45; London Price Current; Posthumus, 1946, I, pp. 66, 74).

\section{SOURCES}

AGI (Archivo General de Indias, Seville): Consulados, legajo 78, no. 84 (blue booklet), Cadiz: 3 August 1802.

AGI, Consulados, libros 1130-1134: Libros de precios corrientes de la Lonja de corredores de Cádiz: 1803-1821. 
AGS (Archivo General de Simancas): Dirección General de Rentas, 20 remesa, legajo 572: "Comercio libre de America. Año de 1783»; legajo 575: "Comercio libre de America. Año de 1788».

AHN (Archivo Histórico Nacional, Madrid): Estado, legajo 3188', Expediente 375-3: Real Proyecto patriotico, Parte tercera, Cap1 9, by Thomas Sothuel, 8 February 1785.

ARdoIn et al. (1845-46): Diccionario Universal..., Málaga: Martínez de Aguilar, 2 vols.

BNA (British National Archives, London; formerly Public Record Office), Board of Customs and Excise Records: Customs 17 (1772-1808).

Balanza del comercio de España con las potencias estrangeras en el año de 1792... (1803). Madrid: Imprenta Real.

Balanza del comercio de España con los Dominios de S.M. en América y en la India en el año de 1792... (1805). Madrid: Imprenta Real.

BeVeridge, W. H. (1939): Prices and wages in England from the twelfth to the nineteenth century, London: Longmans.

Bezanson, A. et al. (1936): Wholesale prices in Philadelphia, 1784-1861, 2 vols., Philadelphia: University of Pennsylvania Press.

Bezanson, A. et al. (1951): Prices and inflation during the American Revolution, Pennsylvania, 1770-1790, Philadelphia: University of Pennsylvania Press.

Correo Mercantil de España y de sus Indias (1792-1808), Madrid: Imprenta de Vega y Compañía.

Course of the Exchange [The], published twice weekly by John Castaign and Edward Wetenhall (microfilm series to 1816 and originals since 1817 in the Goldsmiths Library, University of London).

GAYER, A. D. et al. (1953): The growth and fluctuation of the British Economy, 1790-1850, 2 vols., Supplement, Oxford: Clarendon Press.

Hamilton, E. J. (1988 [1947]): Guerra y precios en España 1651-1800, Madrid: Alianza Editorial.

London Price Current (LPC), various titles («Prince's», The «Universal», «New»), 1779-89.

MARIÉN Y ARRÓSPIDE, T. A. (1789): Tratado general de monedas, pesas, medidas y cambios..., 2 vols., Madrid: Imprenta de D. Benito Cano.

Posthumus, N. W. (1946, 1964): Inquiry into the history of prices in Holland, 2 vols., Leiden: E. J. Brill.

Reglamento y aranceles reales para el comercio libre de España a Indias de 12 de octubre de 1778, eds. B. Torres Ramírez and J. Ortiz de la Tabla, Seville: Facultad de Filosofía y Letras de la Universidad, 1978.

Tooke, T. (1824): Thoughts and details on the high and low prices of the last thirty years, from 1793 to 1822, 4 parts, 2nd ed., London: John Murray.

\section{BIBLIOGRAPHY}

Alonso Álvarez, L. (1986): Comercio colonial y crisis del Antiguo Régimen en Galicia (1778-1818), A Coruña: Xunta de Galicia.

Belloto, M. L. (1971): Correio maritimo Hispano-Americano. A carreira de Buenos Aires (1767-1779), Assis (Brasil): Facultade de Filosofia, Ciências e Letras.

Bernal, A. M. (1987): "Libre Comercio" (1778): Un primer ensayo de modelo general», in J. Fontana and A. M. Bernal, eds., El "comercio libre» entre España y América (1765-1824), 2nd ed., Madrid: Fundación Banco Exterior, pp. 17-51.

Bowen, H. V. (2006): «Mobilising resources for global warfare: the British state and the East India Company, 1756-1815», in H. V. Bowen and A. González Enciso, eds., 
Mobilising resources for war: Britain and Spain at work during the early modern period, Pamplona: EUNSA, pp. 81-110.

Bowen, H. V., and A. GonzÁLEz ENCISO, eds. (2006): Mobilising resources for war: Britain and Spain at work during the early modern period, Barañain (Navarra, Spain): Ediciones Universidad de Navarra, S.A. (EUNSA).

Broeze, F. J. A. (1973): «The New Economic History, the Navigation Acts, and the continental tobacco market, 1770-90», Economic History Review, XXVI, 4, pp. 668-78.

Cuenca Esteban, J. (1978): "The trade and commercial policy of Spain, 1765-1826», unpublished doctoral thesis, University of Toronto.

- (1981): "Statistics of Spain's colonial trade, 1792-1820: Consular duties, cargo inventories, and balances of trade», Hispanic American Historical Review, 61, pp. 381-428.

- (1982): "Comercio y hacienda en la caída del Imperio español, 1778-1826», in J. Fontana, ed., La economía española al final el Antiguo Régimen, III. Comercio y Colonias, Madrid, Bank of Spain/Alianza Editorial, pp. 389-453.

- (1987): «Fundamentos para una interpretación de las estadísticas comerciales francesas, 1787-1821, con referencia especial al comercio franco español», Hacienda Pública Española, no. 108/109, pp. 221-251.

- (1991): «Precios y cantidades en el comercio español con Francia y Gran Bretaña, 1797-1807: Coyuntura internacional y opciones imperiales», Revista de Historia Económica, IX, pp. 127-163.

- (1994): «British textile prices, 1770-1831: Are British growth rates worth revising once again?», Economic History Review, XLVII, 1, pp. 66-105.

- (1997): "The rising share of British industrial exports in industrial output, 17001851 », Journal of Economic History, vol. 57, 4, pp. 879-906.

- (1999): «Factory costs, market prices, and Indian calicos: Cotton textile prices revisited, 1779-1831», Economic History Review, LII, 4, pp. 749-755.

- (2001): «The British balance of payments, 1772-1820: India transfers and war finance», Economic History Review, LIV, 1, pp. 58-86.

- (2004): "Comparative patterns of colonial trade: Britain and its rivals», in L. Prados de la Escosura, ed., Exceptionalism and industrialisation. Britain and its European rivals, 1688-1815, Cambridge: Cambridge University Press, pp. 35-66.

- (2007a): "India's contribution to the British balance of payments, 1757-1812», Explorations in Economic History, 44/1, pp. 154-176.

- (2007b): «Fiscal dimensions of Britain's regulated trade with Asia, 1765-1812», in R. Torres Sánchez, ed., War, state, and development. Fiscal-military states in the eighteenth century, Pamplona: Universidad de Navarra, S.A. (EUNSA), pp. 69-86.

Delgado Ribas, J. M. (1986): «Libre comercio: mito y realidad», in T. Martínez Vera, ed., Mercado y desarrollo económico en la España contemporánea, Madrid: Siglo XXI de España, pp. 69-83.

- (1989): Comercio colonial y crecimiento económico (1776-1808). Una interpretación a partir de los precios, Bellaterra: Institut d'Anàlisi Econòmica.

- (1992): «El impacto de la reforma del "comercio libre" sobre el comercio colonial español», in J. Casas Pardo, ed., Economic effects of the European expansion 14921824, Stuttgart: F. Steiner, pp. 387-434.

Delgado RIBAS, J. M. et al., eds. (1986): El comerç entre Catalunya i Amèrica (segles XVIII $i X I X)$, Barcelona: L'Avenç.

FÁBregas Roig, J. (2005): "El primer año del libre comercio en Cataluña», in C. Martínez Shaw and J. M. Oliva Melgar, eds., El sistema Atlántico español (siglos XVIIXIX), Madrid: Marcial Pons, pp. 285-309. 
FIsHeR, J. R. (1981): «Imperial "Free Trade" and the Hispanic Economy, 1778-1796», Journal of Latin American Studies, 13, 1, pp. 21-56.

- (1985a): "The Imperial response to "Free Trade": Spanish imports from Spanish America, 1778-1796», Journal of Latin American Studies, 17, 1, pp. 35-78.

- (1985b): Commercial relations between Spain and Spanish America in the era of Free Trade, 1778-1796, Manchester: Manchester Free Press.

- (1992): Trade, war, and revolution. Exports from Spain to Spanish America, 17971820, Liverpool: University of Liverpool, Institute of Latin American Studies.

Fontana LÁzARo, J. (1991): «La crisis colonial en la crisis del Antiguo Régimen español», in H. Bonilla, ed., El sistema colonial en la América española, Barcelona: Crítica, pp. 305-20.

Fontana LÁzARo, J., and A. M. Bernal, eds. (1987): El «comercio libre» entre España y América (1765-1824), 2nd ed., Madrid: Fundación Banco Exterior.

García-BaQuero GonzÁlez, A. (1972): Comercio colonial y guerras revolucionarias, Sevilla: Escuela de Estudios Hispano-Americanos.

- (1974): «Comercio colonial y producción industrial en Cataluña a fines del siglo XVIII», in J. Nadal and G. Tortella, eds., Agricultura, comercio colonial y crecimiento económico en la España contemporánea, Barcelona: Ariel, pp. 268-94.

- (1976): Cádiz y el Atlántico (1717-1778). El comercio colonial español bajo el monopolio gaditano, 2. vols., Sevilla: Escuela de Estudios Hispano-Americanos.

- (2003): El comercio colonial en la época del absolutismo ilustrado: problemas y debates, Granada: Universidad de Granada.

Hussey, R. D. (1934): The Caracas Company 1728-1784. A study of the history of Spanish monopolistic trade, Cambridge: Harvard University Press.

IZARD, M. (1974): «Comercio libre, guerras coloniales y mercado americano», in J. Nadal and G. Tortella, eds., Agricultura, comercio colonial y crecimiento económico en la España contemporánea, Barcelona: Ariel, pp. 295-321.

Labrousse, C. E. (1933): Esquisse du mouvement des prix et des revenus en France au XVIIIè siècle, 2 vols., Paris: Librairie Dalloz.

Llombart, V. (1994): «La política económica de Carlos III). Fiscalismo, cosmética o estímulo al crecimiento?», Revista de Historia Económica, XII, 1, pp. 11-39.

MARICHAL, C. (1997): "Beneficios y costes fiscales del colonialismo: las remesas americanas a España, 1760-1814», Revista de Historia Económica, XV, 3, pp. 475-505.

- (1999): La bancarrota del Virreinato: Nueva España y las finanzas del Imperio español, 1780-1810, Mexico City: El Colegio de Mexico, Fondo de Cultura Económica (Fideicomiso Historia de las Américas).

Martínez SHaw, C. (1987): «El libre comercio y Cataluña: Contribución a un debate», in J. Fontana and A. M. Bernal, eds., El «comercio libre» entre España y América (1765-1824), 2nd ed., Madrid: Fundación Banco Exterior, pp. 43-51.

Merediz, R. (1966): «Comercio de frutos del país entre Buenos Aires y mercados europeos entre 1815 y 1820», Trabajos y Comunicaciones, 15, pp. 136-52.

MERINO, J. P. (1987): Las cuentas de la administración central española 1750-1820, Madrid: Instituto de Estudios Fiscales.

MoRINEAU, M. (1985): Incroyables gazettes et fabuleux métaux: les retours des trésors américains d'aprés les gazettes hollandaises (XVIe-XVIIIe siècles), London: Cambridge University Press; Paris: Maison des Sciences de l'Homme.

O'Brien, P. K. (1988): "The Political Economy of British taxation, 1660-1815», Economic History Review, 41, 1, pp. 1-32.

Oliva Melgar, J. M. (1987): Cataluña y el comercio privilegiado con América en el 
siglo XVIII: La Real Compañía de Comercio de Barcelona a Indias, Barcelona: Universitat de Barcelona.

Ortiz de la Tabla Ducasse, J. (1978): Comercio exterior de Veracruz 1778-1821. Crisis de dependencia, Sevilla: Escuela de Estudios Hispano-Americanos.

Pearce, A. J. (2007): British Trade with Spanish America, 1763-1808, Liverpool: Liverpool University Press.

Prados de la Escosura, L. (1988): De imperio a nación. Crecimiento y atraso económico en España (1780-1930), Madrid: Alianza Editorial.

- (1993): "La pérdida del Imperio y sus consecuencias económicas», in L. Prados de la Escosura and S. Amaral, eds., La independencia americana: consecuencias económicas, Madrid: Alianza Editorial, pp. 253-300.

Tedde DE LorCA, P. (1989): «Política financiera y política comercial en el reinado de Carlos III», in Actas del Congreso Internacional sobre "Carlos III y la Ilustración», 3 vols., Madrid: Ministerio de Cultura, II, pp. 139-217.

Torres SÁnchez, R. (2007): «Possibilities and Limits: Testing the Fiscal-Military State in the Anglo-Spanish War of 1779-1783», in R. Torres Sánchez, ed., War, state, and development. Fiscal-military states in the eighteenth century, Pamplona (Spain): Ediciones Universidad de Navarra, S.A. (EUNSA), pp. 437-460.

TORRES SÁNCHEZ, R., ed. (2007): War, state, and development. Fiscal-military states in the eighteenth century, Pamplona (Spain): Ediciones Universidad de Navarra, S.A. (EUNSA). 